The University of San Francisco

USF Scholarship: a digital repository @ Gleeson Library |

Geschke Center

Economics

College of Arts and Sciences

2010

\title{
Does Social Capital Matter? Evidence from a Five- Country Group Lending Experiment
}

Alessandra Cassar

University of San Francisco, acassar@usfca.edu

Bruce Wydick

University of San Francisco,wydick@lucas.usfca.edu

Follow this and additional works at: http://repository.usfca.edu/econ

Part of the Economics Commons

\section{Recommended Citation}

Alessandra Cassar and Bruce Wydick. Does social capital matter? Evidence from a five-country group lending experiment Oxf. Econ. Pap. (2010) 62 (4): 715-739 doi:10.1093/oep/gpq010

This Article is brought to you for free and open access by the College of Arts and Sciences at USF Scholarship: a digital repository @ Gleeson Library | Geschke Center. It has been accepted for inclusion in Economics by an authorized administrator of USF Scholarship: a digital repository @ Gleeson Library | Geschke Center. For more information, please contact repository@usfca.edu. 


\title{
Does Social Capital Matter? Evidence from a Five-Country Group Lending Experiment
}

JEL Classifications: O12, O16, C92, Z13

\author{
Alessandra Cassar and Bruce Wydick \\ Department of Economics \\ University of San Francisco \\ 2130 Fulton St. \\ San Francisco, CA 94117 \\ e-mail:acassar@usfca.edu, nydick@usfca.edu
}

May 2009

\begin{abstract}
Does social capital matter to economic decision-making? We address this broad question through an artefactual group lending experiment carried out in five countries: India, Kenya, Guatemala, Armenia, and the Philippines, obtaining data from 10,673 contribution decisions on simulated group loans from 1,554 participants in 259 experimental borrowing groups. We carry out treatments for social homogeneity, group monitoring, and group self-selection. Results show that societal trust has a positive and significant impact on group loan contribution rates, that group lending appears to create as well as harness social capital, and that peer monitoring can have perverse as well as beneficial effects.
\end{abstract}

Both authors wish to thank Luke Crowley, Jean-Paul Petraud, Jason Trimiew, David Thompson, Ill Hong Yoo, Justus Shoyero and Chris Wendell for outstanding help with experiments and data collection, along with Chris Ahlin, Jenny Aker, Alain de Janvry, Esther Duflo, Dan Friedman, Xavier Giné, Michael Jonas, Craig McIntosh, Dean Karlan, Stefan Klonner, Ashok Rai, Elizabeth Sadoulet, and Dean Scrimgeour for helpful comments and input on this research. Grant funding from the Jesuit Foundation and the McCarthy Foundation is gratefully acknowledged. 


\section{Introduction}

Economists have become increasingly fascinated by the role that social capital plays in facilitating economic transactions. Particularly in communities that are relatively homogeneous and close-knit, social capital may facilitate a general sense of trust and goodwill surrounding economic exchange. Social capital may also facilitate the flow of information, serving a screening function that curtails adverse selection. Further, it may help hold people more accountable for their actions, mitigating moral hazard as economic decisions are placed within the context of long-term relationships.

Understanding the effect of social capital on economic decision-making has been the subject of a broad literature. This literature has pointed to the positive effects of social capital on economic growth (Knack and Keefer, 1997), reducing corruption (LaPorta et. al., 1997), community governance (Bowles and Gintis, 2002), preventing crime (Case and Katz, 1991), curtailing moral hazard in the workplace (Ichino and Maggi, 2000), and financial development (Guiso, Sapienza, and Zingales, 2004).

Yet it is often the case that social capital variables are endogenous to outcome variables, presenting a challenge to causal inferences. Some rigorous studies on the economic effects of social capital have used instrumental variables to address problems of correlated unobservables (e.g. Knack and Keefer (1997) or exploited differences in regional social capital within a country to identify its effects (e.g. Putnam, 1993; Ichino and Maggi, 2000). Our study addresses the challenge of causal inference through experimental methods. We carry out a group lending experiment in five countries with five very different cultural contexts to test the effect that different types of social capital have on an individual's propensity to contribute to a joint liability loan.

Our experiments were carried out in Armenia, Guatemala, Kenya, India, and the Philippines among a total of 1,554 participants in 259 simulated borrowing groups across these five countries. In our group lending experiment, each subject in a group is given a "loan" and then must draw a ball at random from a black bag that contains five green balls and one red ball. Drawing a green ball means a successful investment from which the subject earns a positive return, giving the subject the opportunity to contribute to the repayment of the group loan. Drawing the red ball implies a negative shock to the borrower in which the borrower is unable to pay her share of the group loan. Subjects choose balls with replacement, so that there is a one-sixth probability that any of the subjects draws the red ball, even after it has already been drawn. If at least half of the subjects in a group contribute, group lending continues for a subsequent round with each member receiving an additional loan. This process of group repayment, if sustained for more than a few rounds, can make each member better off relative to non-repayment because non-repayment increases the 
likelihood of group loan termination. Consequently, each individual faces a trade-off between contributing to the group loan (to help the group to continue to receive loans) and withholding her contribution (increasing her individual payoff for a particular round) ${ }^{1}$. Because each group lasted an average of 6.86 rounds before breakdown from insufficient repayment occurred, our study generated 10,673 observations from which to draw in our analysis.

Our five-country experiment is designed to examine the more general question of the effect of social capital on economic decision-making, but also to test some hypotheses in the literature that are germane to microfinance and group lending. A number of theories have been advanced in the field of microfinance seeking to explain why group lending is often associated with high repayment rates. In short, these theories posit that a significant measure of the success of group lending is derived from its ability to harness the social capital that is pervasive within traditional societies in order to overcome credit market failures. ${ }^{2}$ Leading theories argue that (1) Self-selection of borrowing groups implies an assortative matching process, based on local information, in which safe borrowers join with other safe borrowers, while risky borrowers are culled from the portfolio or are forced to internalize the consequences of their behavior, thus mitigating adverse selection problems (Van Tassel, 1999; Ghatak, 1999); (2) Peer monitoring between jointly liable borrowing group members helps mitigate the hidden action that spawns moral hazard in credit transactions (Stiglitz, 1990; Banerjee, Besley, and Guinnane, 1994; Wydick, 2001); (3) Social ties and the resulting potential for sanctions between members may also help mitigate moral hazard problems in joint liability lending contracts when borrowers enjoy a social leverage with one another that extends beyond the lending contract (Floro and Yotopolous, 1991; Besley and Coate, 1995).

Information about other people, about what they are doing, and the potential to influence their behavior each represents a different facet of social capital. Accordingly, we designed our treatments in our group lending experiment around these phenomena in a between-subjects design. We implemented group self-selection treatments as part of our work in three of our countries, allowing subjects to bring a self-selected group of friends or acquaintances to the experiment site with who then formed their partners in the experiment. These self-selected groups comprised $16.1 \%$ of the groups in Guatemala, $50 \%$ in Kenya, and $45.5 \%$ in the Philippines. In India (52.9\%)

\footnotetext{
${ }^{1}$ While this group lending game retains some of the flavors of the public good game, it departs from it in substantial ways by having dynamic incentives in the payoffs structure and introducing individual shocks (see our more detailed description in Section 2).

${ }^{2}$ Some of the original work showing that the informational flows and close-knit relationships within traditional societies could overcome information asymmetries in credit markets was undertaken by Udry's (1994) study on credit relationships in Nigeria. Udry showed that the implicit terms of credit contracts were designed to accommodate shocks to both borrowers and lenders during the term of a loan, making them less sensitive to asymmetric information issues than credit contracts in more developed economies.
} 
and the Philippines $(11.0 \%)$ a portion of our experimental groups were comprised of actual selfselected group borrowers from a local microfinance institution (MFI),

In two countries we implemented a monitoring treatment, comprising $14.5 \%$ of the groups in Guatemala and $25.5 \%$ in the Philippines. In our normal set-up, chairs were facing away from the other subjects around a circle, so that subjects chose balls and made contributions choices privately with the experimenter. In the monitoring treatments, subjects performed both of these tasks in front of the group so that others could observe not only what color ball each drew, but whether or not another member drawing a green ball was choosing to use her good fortune to contribute to the group loan. After observing contributions of the other members, we allowed subjects to alter their decisions by flipping contribution decision cards until subject decisions converged to a Nash equilibrium.

To test for the importance of social ties, social homogeneity, and the potential for social sanctions on economic behavior, we exogenously formed the remaining groups in terms of homogeneity and heterogeneity over key social reference groups. In our 26 groups in Armenia, we formed groups exogenously over a main source of social conflict in that country, between prePerestroika and post-Perestroika generations. In Guatemala we formed homogeneous and heterogeneous groups based on subjects' residence in one of two rival towns adjacent to one another. Because evangelical Protestants now make up nearly half of the country's population, we also purposely formed homogeneous and heterogeneous groups of Evangelicals and of Catholics, with each subject announcing his or her residence and religion to the others as part of a personal introduction before the experiment. In 23 of our 46 groups in Kenya we did the same with Muslims and Christians, and similarly in 30 of our 55 groups in the Philippines with homogeneous and heterogeneous groups of Muslims and Christians. Our Indian site was the most religiously diverse, and in 33 of our 70 groups in Chennai we created homogeneous groups of Hindus, Muslims, and Christians along with groups of half Hindus and Christians and half Hindus and Muslims.

In each of our country sites we had subjects fill out a survey in which they answered questions about the depth of their relationship with others in the group, how long they had lived in the area, questions regarding the depth of their religious commitment, their views of people from other groups, answers to the three standard questions on societal trust from the General Social Survey, and information on other standard control variables.

We will summarize briefly some of the main results from our study, providing more results and more details of these results in the main body of the paper. In general we find some basic factors to influence contribution decisions in virtually every context. For example, we find strong evidence of reciprocity: Subjects victim to a greater number of negative shocks (red balls) contribute 
more often when they draw a green ball and have the opportunity to contribute. In virtually all of our estimations across countries we find a significant and positive correlation between a person being more trusting of others in society (based on their answers to the standard GSS questions) and group loan contribution decisions. We find this effect across groups, within groups (using grouplevel fixed effects), and positive point estimates in virtually every type of country estimation. Across countries, we generally find age to facilitate the rate of contribution, and education level to be irrelevant. We also find in our group self-selection treatments that when subjects self-selected with borrowers with whom they knew, contribution rates increased. But there are also a number of surprising results, some of which yield new insights into the relationship between social capital and economic decision-making.

One of the starkest results from our study regards the dramatically lower rates of individual contribution rates and lending group duration in the Nairobi, Kenya experiments relative to the other country sites. While the average individual contribution rate (contributions to the group loan after drawing a green ball) for the 1,278 subjects in the other four countries was $87.5 \%$, among the 276 subjects in Nairobi it was only 41.8\% $(p=0.000)$. While contribution rates in the other four countries were sufficiently high that the average experimental borrowing group was able to continue to receive loans for 7.95 rounds, in Nairobi the average group duration was only 1.80 rounds $(p=0.000)$. The explanation for this substantial difference became clear from the exit interviews carried out with subjects after game play. Subjects in Nairobi began the experiment with the belief that others would fail to contribute to the group loan. We demonstrate that given this belief a decision not to contribute is rational, but in Kenya such priors created a self-fulfilling prophecy in which lending was terminated at an early stage, and final payoffs to the subject/borrowers were much lower than in the other countries.

One of the most important findings from our study is that the effects of different types of social capital are highly contextualized. For example, acquaintanceship with other members of the group and the number of years subjects lived in an area had strong effects in some countries, and weak or even negative effects in others. Furthermore, much of the evidence from our study points to the danger of over-generalizing about the nature of social capital in developing countries and its effect on economic behavior. That different aspects of social capital appear to exhibit diverse effects across cultures suggests that the external validity of work in behavioral economics and social capital carried out in a single context may be quite limited. In this respect our results support existing research such as Henrich et. al. (2001), in which the authors found substantial differences in plays of the ultimatum game when carried out in 15 different small-scale societies across Africa, Asia, and Latin America. 
One of our most important treatments was in artificially constructing homogeneity and heterogeneity by religion within our experimental borrowing groups. We found the importance of social homogeneity to repayment of our experimental group loans to be fairly weak, even across groups between which significant social tension exists. Although we find consistently positive point estimates from homogeneity on group duration across all countries, only one estimate on individual contribution is statistically significant at the country level: our estimation on individual contributions by round using group-level fixed effects. Thus we find very mild effects at best of group religious homogeneity despite the fact that the religious affiliation of members in our groups was clearly manifest to subjects before the experiment began.

We find moreover, that certain facets of social capital may exhibit surprising effects, which may generate unanticipated Nash equilibria when isolated for study in group interaction. An example from our study concerns the effects of monitoring. Unlike our normal treatments in which subject shocks and contributions were hidden information, in our monitoring treatments subjects observed the color of the ball drawn by each member of the group in each round as well as their contribution decision. Our prior, based on standard theory, was that we would find little if any instances of defection with perfect monitoring. Yet what we did find is that mutual monitoring did not improve repayment rates in the experiment, and in the Philippines resulted in lending being terminated an average of three rounds earlier than without monitoring. Indeed, there appear to be two counteracting effects from monitoring: a "shame" effect, which tends to encourage members to contribute their share (especially when others in the group are contributing), and a "retaliation" effect, in which other members retaliated in response to a defection. We observed subjects flip their cards en masse to non-repayment when observing a defecting member drawing a green ball and choosing not to repay. We show here that, in their desire to punish the flagrant non-contributor, these retaliations acted against subjects' own pecuniary interests. ${ }^{3}$ While peer monitoring results in higher repayment conditional upon every other member in the group contributing, when even one other individual in the group refused to repay after drawing a green ball, the repayment rate with peer monitoring quickly became lower than with no peer monitoring at all. Because the latter typically resulted in immediate termination of lending to the group, we find that the retaliation effect at least counteracts the shame effect, and if anything outweighs it.

Another finding from the study that is perhaps less surprising is that real-world microfinance borrowers are different from the general population in important ways: In both India and the Philippines, where we included real-world microfinance borrowers in a large fraction of our

\footnotetext{
3 The retaliation effect witnessed in our experiment can be compared to that which has been documented repeatedly in experiments using the Ultimatum game, in which players often reject a positive offer from an initial player at a cost to themselves. See, for example, Guth and Tietz (1990).
} 
experimental population, their rates of contribution were significantly higher than our remaining sample of subjects who fit the external profile of microfinance borrowers based on observable characteristics, but were not actual microfinance borrowers. Moreover, in both regression estimates controlling for other variables and in Mann-Whitney tests we find that subjects from real borrowing groups (with zero dropouts) who had already taken loans contributed at a higher rate than borrowing groups in our study who were formed, but hadn't yet taken loans. Thus we find evidence that group lending seems to not only harness social capital, but create social capital in the repeated process of joint borrowing and repayment. Such results give us reason to think this phenomenon may apply in other contexts as well; economic activity seems to create social capital rather than just simply harness existing social capital to facilitate transactions as has been emphasized previously.

Following this introduction, Section 2 of our paper presents a description of our group lending experiment, experimental settings in our five country sites, and an analysis of the strategic interdependence characterizing the experiment. Section 3 examines our main results across our five country sites, focusing on the social homogeneity, monitoring, and self-selection treatments carried out in the experiments. Section 4 summarizes and concludes.

\section{The Experiment}

\subsection{Experimental Design}

The group lending experiment that we employ in each of the five country sites is the group lending game originally developed by Abbink, Irlenbusch, and Renner (2006) with some modifications and adjustments for particular treatments. We favor the game because it contains three important properties that capture key aspects of group lending: The first is that it incorporates dynamic incentives. Field research has indicated that a major reason borrowers repay group loans is to maintain access to future loans. ${ }^{4}$ The second is that it incorporates a key form of moral hazard: difficultly in eliciting repayment even when a project yields a sufficient return. The third is that the structure of the game allows for private information; investment shocks are private information in the standard execution of the game, but the game can easily be adapted to allow for a peer monitoring treatment.

Our experimental setup consisted of a circle of chairs facing away from the center of the circle (except for the monitoring treatments, in which the chairs faced inward.) Each member of the group introduced him or herself to the other five members of the borrowing group, giving a short introduction which included a clear statement of his or her religion. ${ }^{5}$ The experimenter read

\footnotetext{
${ }^{4}$ See for example, Wydick (2001) which reports that $86 \%$ of microfinance borrowers when asked why they choose to repay their share of a group loan respond that they do so to maintain access to MFI credit.

${ }^{5}$ Religious introductions were performed in Guatemala, Kenya, India, and the Philippines.
} 
directions, answered clarifying questions, and carried out three pre-determined trial runs of the experiment with the group, asking questions to the subjects after the trial runs to ascertain their knowledge of how the experiment worked.

In the experiment each of the six subjects is given a "loan" equal to approximately US $\$ 0.50$. For example, in India the initial loan to each subject was 20 rupees. This creates a jointly liable loan for 120 rupees that must be repaid at 20 percent interest for a total of 144 rupees. The experimenter then passes a black bag with six colored ping-pong balls to each subject, who draws one ball, notes the color of the ball with the experimenter, and then returns the ball to the bag. The color of the ball is then marked with ink on a card held by the subject. There are five balls in the bag, five green and one red. Except in the case of the monitoring treatment, only the experimenter and the subject know the color of the ball each subject has randomly chosen. After the subjects have chosen balls, the experimenter makes another trip around the circle to record the contribution of each group member to the joint liability loan. If the subject draws a red ball, the subject receives a negative shock on her investment; she loses her principal and cannot repay her share of the group loan. If she receives a green ball, then must choose whether or not to contribute to repayment of the loan by displaying a decision card privately to the experimenter. For example in India (the Philippines), the payoff to a successful investment was 48 rupees (pesos). With all six members contributing to a loan in India, each member would contribute 24 rupees to pay off the 144 due on the loan and keep 24 rupees. However, if the number of contributors is smaller, as with real-world group lending, the contribution of the other members must increase.

Continuing with the India example, if the number of contributors ended up being four, each would have to contribute 36 rupees, while keeping only 12 rupees as a payoff from that round. Since it requires 144 rupees to pay off the group loan, full repayment is impossible if fewer than three borrowers contribute to repayment. Thus if three or more borrowers contribute, the group receives another loan in a subsequent round, but if less than three contribute, lending ceases and the experiment ends with subjects receiving their payoffs accrued from each round they participated in. Subsequent to each round, the experimenter informed players about the total number of contributors (but not their identities), and if repayment was sufficient to foster another loan. After the experiment, subjects filled out a questionnaire with approximately 50 questions pertaining to demographic, social, religious variables, and social trust. ${ }^{6}$

\footnotetext{
${ }^{6}$ We used three GSS questions in each country that included the question on trust "Generally speaking, would you say that most people can be trusted or that you can't be too careful in dealing with people?", the question on fairness, "Do you think most people would try to take advantage of you if they got the chance, or would they try to be fair?", and the question on helpfulness, "Would you say that most of the time people try to be helpful, or that they are mostly just looking out for themselves?". Because these questions are highly related, in our estimations we create a composite index equal to the number of answers reflective of a positive level of societal trust from the three questions.
} 
Our research team of faculty and graduate students received uniform training sessions for carrying out the experiments with multiple practice trials carried out on university subjects. Yet there were necessarily minor differences in the way our research team implemented the group lending experiment in the different country sites. We attempted to create similar payoffs between countries such that if a group was moderately successful (say, lasting six or seven rounds), the net payoff to each subject would equal approximately one day's wages in the course of less than two hours. Members of groups lasting more than ten rounds earned up to two or even three days wages in some cases, but cross country differences were not exact. Moreover, the experiment is most easily carried out when using numerical payoffs easily divisible by as many small integers as possible, such that an exact cross-country conversion was infeasible in any respect given the use of five different currencies.

Secondly, our research team was divided across countries, so that at each country site the experiment was carried out by two or three different experimenters (with some overlap), so that while we made every effort to minimize differences in execution between countries through uniform training sessions, small differences in presentation undoubtedly exist.

Another difference concerned our effort to minimize the tendency toward end-game defections manifest in any finitely repeated game. After the 10th round (sixth round in Armenia), slightly different devices in some countries were used to bring the experiment to a close to avoid the pitfalls associated with a finitely repeated game. In Armenia and Guatemala, a coin was flipped so that there was only a one-half probability of continuing to the next round. In the Philippines and India, the probability of a negative shock to a borrower's experiment increased from $1 / 6$ to $1 / 2$ after the tenth round, generating approximately the same probability of termination. In Kenya, lending groups collapsed sufficiently early that no such device was deemed necessary. All of these endgame implementations were unannounced to borrowers at the beginning of the game, except in Armenia where borrowers knew that the probability of continuation would be one-half beginning in the seventh round. Interestingly, while the theory of finitely repeated games would predict higher rates of defection in this context, group loan contribution rates in Armenia were almost exactly equal to the average contribution rate across countries, $75.5 \%$.

While any significant impact from these differences should be absorbed by the country fixed effect, any specifically cross-country analyses should take these caveats into consideration.

\subsection{Sites and Subjects}

In each of our country sites our subjects were borrowers who fit the typical profile of a microfinance borrower: living in a relatively poor neighborhood with relatively low levels of formal schooling, average age about 34 years old, and disproportionately women (80.8\%). Subjects were 
typically recruited in collaboration with local NGOs (non-government organizations). In India and the Philippines we ran a large fraction of our experiments on actual microfinance borrowers who were current borrowers with a local MFI, such that real microfinance borrowers make up 16.6 percent of our subjects in the study as a whole. Some of the non-microfinance borrowers had participated in programs of the local NGO or were recruited off the street for the experiment. When we ran treatments allowing for self-selection of borrowers, we spread the word generally among a segment of the local population fitting our profile, giving a rough description of the activity, and encouraged subjects to arrive at the experiment site in self-selected groups of six.

Our study provides a rich variation of contexts to study the effects of social capital on economic decision-making:

\subsubsection{Berd, Armenia}

The data from our 26 groups in Armenia, which formed the basis for our initial study using the group lending experimental methodology (Cassar, Crowley, and Wydick, 2007), comprises only 6.25 percent of the observations used in the present five-country study. In Armenia we carried out our experiment at the Artig Business Company in Berd, Armenia (population. 8,700) in April, 2005. All of the subjects in Armenia were women, and in Armenia, as in the other country sites, subjects were required to be at least eighteen years old. Because of the strident changes in Armenian culture since the collapse of the old Soviet Union, the biggest social division between local residents was generational: pre- versus post- Perestroika generations, where the difference in social outlook and social values was said to differ between the two considerably. We therefore randomly assigned subjects to groups to exogenously generate measures of generational diversity.

\subsubsection{San Pedro Atitlan, Guatemala}

Our 62 group experiments in Guatemala were carried out in the adjacent towns of San Pedro Atitlan and San Juan Atitlan (population of both approximately 4,000) in June-July, 2006. In Guatemala 90.1 percent of our subjects were women, none being recipients of microfinance loans. All of our subjects were of Mayan ancestry, typically speaking the native Tzutujil as a first language and Spanish as a second language. Many female subjects earned income from weaving traditional clothing and selling it to local buyers. Other occupations for female subjects included selling bread on the streets to tourists or operating small, family stores. Men in the area typically make a living harvesting coffee, in construction, or in the local tourist industry. In Guatemala, 10 of the groups were self-selected, but in the remainder we formed groups that were purposely homogeneous and heterogeneous by religion, since a major social division in Guatemala lies between Evangelicals and Catholics, who each make up about 50 percent of the population in the Western Highlands. There is also considerable rivalry between the two neighboring towns due to conflicts 
over ownership of coffee-growing land. Therefore we also created groups that were homogeneous and heterogeneous by town of residence so that in each group we had two parameters of possible heterogeneity, by religion and by town. Among nine of the groups in Guatemala we randomly carried out the monitoring treatment, in which subjects could observe positive and negative investment shocks and the contribution decisions of others.

\subsubsection{Chennai, India}

We carried out the experiment on 70 groups in Chennai, India (formerly known as Madras, population 4.3 million) in coordination with Growing Opportunity Finance, a local MFI affiliated with Opportunity International, a major worldwide microlender. The experiments were carried out in December 2006 and January, 2007. Out of the 70 experimental groups, 37 of them were groups of six borrowers taken from actual microfinance borrowing groups. Because borrowing groups with the institution averaged 15-20 members, we often created two or three experimental groups from a single real-world borrowing group. The remaining 33 groups were made up of non-MFI subjects, but who fit the general microfinance borrower profile. From these we created exogenously formed groups that were homogeneous and heterogeneous with respect to the three major religious groups in Chennai: Hindus, Christians, and Muslims. In Chennai itself, the distribution of the population by religion is approximately 82 percent Hindu, 9 percent Muslim, and 8 percent Christian, the most notable social division in local culture. The distribution of groups we formed based on religion was as follows: 10 homogeneous groups of all Hindus, 6 homogeneous groups of all Christians, 9 heterogeneous groups of three Christians and three Hindus, 3 homogeneous groups of all Muslims, and 5 heterogeneous groups of Muslims with either Hindus, Christians or both.

\subsubsection{Nairobi, Kenya}

In Nairobi (population 2.9 million), our experiment was carried out on 46 experimental groups at two experimental sites, one in Kibera, an inner-city slum of Nairobi and another site on the outskirts of the city, in Ongata Rongai. ${ }^{7}$ The experiments took place July-August 2006 and January-February 2007. Nairobi has experienced a tremendous amount of population inflow from outlying areas in Kenya, and even from neighboring countries where there has been civil unrest. Estimates of the percentage of Muslims in Kenya vary, but the consensus seems to be that approximately $10 \%$ of the population is Muslim, where in some areas tensions run high between the two groups. To test for the effects of social homogeneity, Muslims were over-represented in our sample. With exactly half (23) of our groups, we created groups that were either all-Muslim or allChristian or half of each. The remaining 23 groups were self-selected, coming to the site together to

\footnotetext{
${ }^{7}$ Kibera has been an epicenter of much of the recent violence that has taken place in Kenya as a result of the disputed December 2007 elections.
} 
participate in the experiment. The Nairobi experiment had the highest percentage of male subjects (58.7 percent), and while we ensured that all of the subjects fit the general microfinance borrower profile, none had participated in a microlending program.

\subsubsection{Davao, Panabo, and Cotabato Cities, the Philippines}

Each of the three sites for our 55 groups from the Philippines was located on the island of Mindanao, a region of the Philippines well-known for tensions between Muslim and Catholic social groups. From decades of fighting between Muslim separatist groups and the Philippine army, religion has become a transparent social distinction on the island. Experiments were conducted on sites in Davao City (population 1.4 million), Panabo City (population 134,000) and Cotabato City (population 162,000). Participating in the study were 11 (exogenously formed) homogeneous Catholic groups, 10 homogeneous Muslim groups, and 9 heterogeneous groups with three Muslims and three Catholics. There were also 25 self-selected groups, 14 of which received the monitoring treatment. Of the 11 self-selected groups without the monitoring treatment, six were new microfinance borrowers involved with the Panao Multi-Purpose Cooperative, an MFI, while the remaining self-selected groups were taken from local vendors' market associations. The subjects in the Philippines were 70.1 percent female.

\subsection{Understanding the Incentive Structure of the Group Lending Game}

A brief analysis of the experiment helps to understand the incentives faced by subjects, which, as we will demonstrate, replicate some of the important aspects of the strategic interdependence involved with actual group lending. Let $G=\{1,2, \ldots N\}$ represent a borrowing group of $N$ members denoting $i \in G$ as a representative member. Further, let $p$ represent the probability of a successful investment by any member, a probability that is constant and independent across $i$. $R$ is the gross return on an individual investment, and $D$ is the collective amount due on the group loan between the $N$ members. Note that the game is always calibrated such that $D=\frac{R N}{2}$, i.e. that at least half of the group must contribute for the loan to be repaid, and for lending to continue for another round. Further, let $n$ represent $i$ s expectation about the number of the other $N-1$ members $\sim i$ in $G$ who will contribute to the loan given a successful investment, and let $k$ be the actual number of contributors in a round given the probability $(1-p)$ of a failed investment.

The Contribute strategy yields a lower payoff to a subject for the immediate round, but results in an expected probability $\delta_{C}$ that at least $N / 2$ members contribute to the group loan repayment in that round. The Withhold strategy results in a higher (per round) payoff of $p R$, but 
reduces the likelihood of a subsequent loan to $\delta_{N}<\delta_{C}$. Given these probabilities $\delta_{N}$ and $\delta_{C}$ of continuation, the Contribute strategy will yield a higher payoff than a Withhold strategy if

$$
\begin{gathered}
\frac{p\left(R-\frac{N R}{2(p n+1)}\right)}{1-\delta_{C}}>\frac{p R}{1-\delta_{N}} \text {, where given } N=6 \text { we have } \\
\delta_{C}=1-\sum_{k=0}^{\frac{N}{2}-1}\left\langle_{k}^{n+1}\right\rangle p^{k}(1-p)^{n+1-k}=\frac{(n+1) !}{(n+1) ! 0 !} p^{0}(1-p)^{n+1}+\frac{(n+1) !}{n ! 1 !} p^{1}(1-p)^{n}+\frac{(n+1) !}{(n-1) ! 2 !} p^{2}(1-p)^{n-1} \\
\text { and } \delta_{N}=1-\sum_{k=0}^{\frac{N}{2}-1}\left\langle_{k}^{n}\right\rangle p^{k}(1-p)^{n-k}=\frac{n !}{n ! 0 !} p^{0}(1-p)^{n}+\frac{n !}{(n-1) ! 1 !} p^{1}(1-p)^{n-1}+\frac{n !}{(n-2) ! 2 !} p^{2}(1-p)^{n-2}
\end{gathered}
$$

By substituting in our probability $p=5 / 6$, we can use (1) to obtain the optimal strategy for subject $i$ given the number of the remaining five players she expects will contribute to the group loan when they are able. What becomes clear from this exercise is that as $n$ grows, the optimal strategy of member $i$ switches from Withhold to Contribute. Clearly when beliefs are such that $n \leq 2$, it is optimal for $i$ to play Withhold. Because the game will end after the current round, the payoff from contributing is zero and the expected payoff to Withhold is $p R$, or, normalizing $R$ to unity, 0.833. When three other players contribute, using (1) we find that the expected whole-game payoff from Contribute is 0.90 and from Withhold it is 1.98; thus with $n=3$ it still pays to Withhold. With $n=4$, however, Contribute begins to edge ahead of Withhold, yielding 7.22 versus 6.32. At $n=5$, Contribute yields an expected whole-game payoff substantially greater than Withhold, 40.16 versus 23.48. This creates an incentive structure in which optimal strategies are governed by expectations about others. Consequently, trust between members is thus crucial to cooperative play, sustainability of the exercise, and, ultimately, payoffs.

But like real-world group lending, beliefs about the motives and strategies of other members are likely to change as the exercise progresses. Group members will update their priors about others' play based on the number of contributors $k$ announced at the end of each round. If, for example, the number of contributors is consistently averages less than five out of six, then a prior that all of the other members are playing the Contribute strategy may be revised downward. ${ }^{8}$ A large

8 This would hold true, of course, if member $i$ is playing the Contribute strategy. 
number of non-contributors in a particular round (which plausibly could have been caused by the bad luck of several negative shocks to investments) may quickly trigger a subsequent round in which group members revise their priors over $n$ downward, inducing them to play the Withhold strategy, and thus ending the game abruptly.

\section{Results: Does Social Capital Matter?}

\subsection{Subject Backgrounds}

Figure 1 shows group duration by round for each country. As groups repay loans, they continue to receive new loans, with the highest average group duration in Guatemala ( 9.2 rounds) and the lowest in Kenya (1.8 rounds). We present data on experimental outcomes, personal characteristics of subjects, treatments, social capital and religion variables for each country and for the entire study in Table 1. The mean age of our subjects varied little between the five countries, ranging from 30.2 years in Kenya to 36.1 years in Armenia with a standard deviation equal to approximately 10 in all countries. Education, however, varied substantially between countries with the average subject lacking middle school education in Guatemala, but having middle school education in Armenia and somewhat beyond this in the Philippines. The fraction of female subjects ranged from 0.41 in Kenya, 0.70 in the Philippines, and 0.90 in Guatemala, to entirely female in Armenia and India.

The average fraction of a subject's life lived in the region of the experiment varied from 0.44 in Kenya, where many slum dwellers had relocated to Nairobi from outlying areas, to 0.95 in Guatemala, in which there is traditionally very little mobility between rural towns. In Armenia while the average number of other subjects in the six-person experimental group known by a subject was only 1.43, in the other four countries it ranged between 3.20 and 3.85 out of five. Roughly half of our subjects operated their own enterprises in the sample (about two-thirds in India), and about one quarter were wage workers (just over a third in the Philippines).

The fraction who had experience taking a formal loan varied substantially between the five countries: 0.05 in Armenia, 0.10 in Kenya, 0.52 in India, 0.34 in Guatemala, and 0.42 in the Philippines. We compiled a simple index of societal trust for each subject based on the number of "yes" (trusting) answers to the three standard GSS questions. The level of societal trust varied somewhat between countries, but not overwhelmingly, ranging from 1.34 (lowest trust) in Kenya to 1.88 in the Philippines. Overall Hindu subjects made up $17.1 \%$ of our total sample (coming only from India), Muslims made up $16.7 \%$ of our sample (coming from India, Kenya, and the Philippines), Catholics 28.1\% (in Guatemala and the Philippines), and Evangelical Protestants 25.2\% (in Guatemala, India, and Kenya). 


\subsection{Influence of Social Capital on Repayment Decisions}

We present here three basic sets of estimations: (1) On the duration of groups in the experiment in terms of number of lending rounds, where higher contribution rates generally lead to more rounds of borrowing. (2) On individual contributions by round given that a subject had a successful investment and had the opportunity to contribute, in which we can incorporate roundlevel fixed effects; and (3) On the total number of contributions by each subject divided by the number of opportunities to contribute. Each offers distinct advantages in yielding insight into the effects of social capital variables and group interaction on group loan contributions. Table 2 shows regressions based on group longevity in the experiment. The advantage with these estimations is that in some sense they do capture the "success" of a group based on individual and social characteristics and treatments. However, because a random confluence of negative shocks may play a leading role in terminating lending in any particular round, the estimated effect of social capital variables on decision-making is less precise. The advantage of pooled logit estimations on individual contributions by round (given in Table 3) is that they are able to incorporate situation-specific attributes in the experiment such as responses to previous period shocks to self and others. Uncorrected, however, these estimations would overweight the contribution decisions of individuals in "successful" groups that were able to receive loans for more rounds resulting from the unbalanced panel. The OLS estimations on average individual contribution rates (given in Table 4) don't allow for a study of dynamic responses during the experiment, but offer something akin to a "between estimator" where the analysis is carried out at the individual level rather than the round level. In each of our five-country estimations we show results without fixed effects, with fixed effects at the country level, and fixed effects at the group level. We incorporate robust standard errors in our estimations on experimental group longevity, and clustered standard errors at the experimental group level in our estimations on individuals.

\subsection{Country Differences}

As seen in Table 1, there are substantial country differences in outcomes between our country sites. Contribution rates were $90.3 \%$ in Guatemala, 75.4\% in Armenia, 85.4\% in India, $74.0 \%$ in the Philippines, but only $38.7 \%$ in Kenya. These differences seem to be consistent with the expectations that group members took into the experiment about the behavior of other members. Based on (1) group members should contribute to the loan if they believe at least four of the other five members will contribute to the loan when they draw a green ball. In four of the five countries, this generally appeared to be the case, although at any point in the experiment, a confluence of red balls drawn in one round may have caused those expectations to be revised downward. However, in each country we randomly carried out exit interviews with subjects asking 
them to tell us to explain their repayment strategy for the game. It was clear from these interviews in the Nairobi sites that subjects frequently played the Withhold strategy from the onset of the game because they believed other group members would do likewise. These priors coming into the group lending game created a set of self-fulfilling prophesies that resulted in 32 of the 46 groups terminating after the first round. The lack of confidence in fellow group members greatly reduced the whole-game payoffs for all members in the Kenya experiment relative to the other countries. Subjects playing Withhold in groups that failed in the first round earned 100 Kenyan shillings. In contrast, group members in the solitary group that reached 10 rounds in Kenya earned about 450 shillings, comparable to what subjects earned in the other countries with higher contribution rates.

\subsection{Response to Negative Shocks}

As seen in Table 2, negative shocks to investment (random drawings of red balls) have a strong and significant effect on the longevity of groups. Especially when a random cluster of red balls are drawn in a single round it can either terminate the game on its own accord (especially when combined with one or more group members playing Withhold), or result in a downward revision of priors about the rate of contribution among other members. Based on the latter phenomenon, we would expect the propensity to play Contribute to decline based on the number of shocks to others in previous rounds. We observed a remarkable example of this in India, where, by random bad luck, three members of a group drew red balls in the first round (an unlikely event with probability 0.0046), while the other three drew green balls and chose to repay. Since this was a normal run of the experiment without peer monitoring, of course each member had strong reason to believe such an event was caused by a large number of other members playing Withhold in the first round. In the second round, four members then chose to play Withhold, ending the game. The phenomenon may be counteracted in some instances, where to some subjects it may seem increasingly important to play Contribute when the game is teetering on the brink of termination, nevertheless in Table 3 the coefficient on lagged shocks to others in the previous round is consistently negative and significant for all countries in the estimation using group-level fixed effects in column 8.

We find evidence of reciprocity in our experimental data. It appears that the more negative shocks a subject receives, the more likely she is to contribute to the group loan when she has an opportunity to contribute. In Table 4 the coefficient on "Average Subject Shocks" is positive in every country (except Kenya), and significant at the $1 \%$ level in two of the three five-country estimations. We were surprised, however, at the rationale some subjects used to justify their decisions in exit interviews. One subject in India maintained that she played Withhold subsequent to receiving a negative investment shock to make up for the lost income from the previous round. 


\subsection{Personal and Economic Characteristics}

We generally found personal characteristics to have relatively little bearing on a subject's decision to play Contribute or Withhold. An exception is age, which was consistently associated with group duration and higher contribution rates. The measured effect, however, is fairly large in the group estimations in Table 2, where a one-standard-deviation increase in the mean age of a group (5.08 years in Kenya, 6.36 years in the Philippines) is associated with a 0.746 and 2.24 increase, respectively, in the number of rounds a group was able to sustain loan repayment.

We find no significant effect whatsoever on group loan contribution from additional years of education among our subjects across countries. The coefficients on education carry roughly equal positive and negative (insignificant) signs across countries in every estimation.

Just over $80 \%$ of our 1,554 subjects were women. The Mann-Whitney tests in Table 6 show overall mean contribution rates of women in the study to be dramatically higher than men, $77.2 \%$ to $57.3 \%$, a finding entirely consistent with the established wisdom that women repay microfinance loans at higher rates than men. Interestingly, however, the coefficient on gender has an insignificant sign in virtually every estimation, the reason being that control variables such as trust measures absorb some of the higher repayment performance of women.

Our prior coming into the experiment was that business owners might display higher contribution rates than wage earners. As seen in Tables 2, 3, and 4, the data from our experiment display insignificant effects on contribution for business owners across countries. Wage workers, however, do have significantly lower contribution rates in India and Guatemala (in individual repayment decisions).

Previous experience with formal borrowing also displays no consistent effect across countries on individual contribution rates. While in India (Table 2) the association is positive and significant, the Philippines yields the opposite result in Tables 3 and 4. For the other countries the relationship is insignificant. In the estimations on group longevity, there appears to be a weakly positive relationship between previous borrowing in India, but it remains negative in the Philippines.

\subsection{Social and Trust Variables}

Three of our control variables attempted to capture very general aspects of social capital amongst our subjects: fraction of a subject's life lived in the region of the experiment, number of acquaintances within the experimental borrowing group, and general societal trust as measured by responses to three standard questions from the General Social Survey (GSS). Results from the estimations yields no identifiable pattern across countries for the first two variables, although personal acquaintance matters to contribution rates in Guatemala in Table $3(p<0.10)$ and Table 4 
$(p<0.05)$, and the fraction of life lived in the region may have some special contextual effect unique to the Philippines ( $\not \leq 0.10$ Table 3).

We do, however, find positive responses to the GSS social trust questions to have a consistently positive effect on contribution rates across all countries. The variable we create is a simple index of the number of affirmative answers to the three GSS questions that concern whether they generally believe that others in society are (1) trustworthy, (2) fair, and (3) helpful. The GSS coefficients have the expected positive sign for every country in every estimation, and are statistically significant on the individual round estimations (Table 3) and contribution rates (Table 4) in all three types of five-country estimations. This result holds despite the fact that country fixed effects could be absorbing some of the trust measures captured by the GSS questions.

General trust is important to cooperative play in our experiment. Across our five experiment sites, subjects were acquainted with about $2 / 3$ of the other subjects. Even if a subject were to believe every subject whom she knows to be a contributor, a subject must possess some degree of trust in the contributions of the unknown remaining 1/3 to rationalize her own decision to play Contribute. Kenya and Guatemala have the lowest reported scores on the GSS questions (affirmative answers on $44.5 \%$ and $44.7 \%$ of the three questions compared with an average of $58.4 \%$ in the other three countries). But in Guatemala personal acquaintance with other group members appears to compensate for a lack of general societal trust, helping to foster a $90.3 \%$ contribution rate. However, in Kenya the number of acquaintances carries an (insignificant) negative sign; personal acquaintance in the Nairobi slums fails to make up for a lack of general trust.

The GSS variable is significant even when we carry out contribution estimations using group-level fixed effects. This is significant because, to avoid issues with framing, our survey necessarily took place after our experiment. Thus without corroborating our estimations using fixed effects at the group level, we could not be certain that statements of trust resulted from a subject's experience with her borrowing group in the experiment. By using group-level fixed effects in column 8 in Tables 3 and 4, we control for the experience of the group, and obtain the effects of differences in trust within borrowing groups in individual contribution rates. In fact in Table 3 our point estimates are highest and results most highly significant when using group-level fixed effects, and in Table 4 our point estimates are virtually identical in the absence of fixed effects (column 6), using country-level fixed effects (column 7), and using group-level fixed effects (column 8).

\subsection{Group Homogeneity Treatments}

While in Cassar, Crowley, and Wydick (2007) we found that clan homogeneity in South Africa displayed a significant effect on group loan repayment, we find only mild evidence that group homogeneity fosters either higher contribution rates or group longevity. Our treatments for 
homogeneity were oriented around what were perceived as the greatest social divisions in each particular country context. In Armenia our treatments incorporated the significant societal tensions between the pre- and post-Perestroika generations. In Guatemala one of our treatments incorporated residency between one of two rival towns, San Pedro Atitlan and San Juan Atitlan. Serious conflict has emerged over recent decades between these two small towns over problems associated with tourism and drug trafficking in San Pedro. Moreover, income from tourism in San Pedro has been used to purchase coffee farms in San Juan, such that some of the workers of these fields are no longer owners, but employees of the new plantation owners living in San Pedro.

Most of our heterogeneity treatments were implemented across religious boundaries, a critical social delineation in four of our five countries. In Guatemala, we formed experimental borrowing groups which were homogeneously Catholic, homogeneously Evangelical, and mixed groups with three of each, with similar homogeneous and heterogeneous borrowing group treatments among Muslims, Hindus, and Christians in India, Muslims and Christians in Kenya, and Muslims and Christians in the Philippines. We did not take specific denominational data on Christians in India, Kenya, and the Philippines, but the overwhelming majority of Christians in our subject pool were Evangelical/Protestant in the former two countries and Catholic in the latter, and are classified as such in our estimations. We also included a variable for homogeneity of groups by gender although this was not carried out as a specific treatment.

While we find hints of a mild importance of homogeneity on contribution rates and group longevity, we cannot find any consistent pattern of significance across countries for groups homogeneous by religion, age, residence, or gender for individual contribution rates. In Table 2 point estimates are positive for group homogeneity in every country, yet all coefficients are statistically insignificant. In Table 3 we find homogeneity to have a positive coefficient in four of five countries, but significantly negative in the Philippines. In our five-country estimation using fixed effects at the group level, we find that subjects increase their contributions the greater the number of other subjects with the same religion as themselves, a significant effect at the $1 \%$ level, but our estimations on individual contribution rates in Table 4 reveal no statistical significance or consistency of sign. Consequently, while we find hints that homogeneity matters to group performance, the evidence across our five countries indicates that homogeneity may not be as important to group performance as other factors.

\subsection{Self-Selection Treatment}

In Guatemala, Kenya, and the Philippines, we allowed subjects to form their own selfselected experimental borrowing groups. These are distinct from the actual borrowing groups that took part in the experiment in India and the Philippines. Our desire was to test whether self- 
selection would be likely to increase contribution rates (Ghatak, 1999; Van Tassel, 1999), and whether acquaintanceship is important in the self-selection process. An original implementation of the group lending game, among a population of university students, showed that self-selected groups displayed greater volatility in outcomes, higher contribution rates in early rounds, but with contribution rates falling (and groups collapsing) more rapidly in later rounds (Abbink et. al., 2006).

What we find in our self-selection treatments is that self-selection alone does not yield an improvement in contribution rates or group performance, and in fact by itself seems to have a significantly negative effect $(p<0.01$ in all five-country estimations). However, when we interact the self-selection treatment with acquaintance between individuals, we find a strongly significant and positive association with contribution rates and group performance from this interaction: When subjects select others whom they know to become their fellow group members, rather than randomly selecting strangers off the street, it matters.

One might ask why borrowers would form a borrowing group with others whom they do not know well. However, as group lending is carried out in many parts of the world, borrowing groups comprised of members with relatively weak ties are more common than one might surmise. Because microfinance institutions often compel borrowers to form solidarity groups in order to receive loans, those with a dire need for credit will sometimes hastily create a borrowing group of members with relatively weak social ties. Our results seem to provide some evidence that in contexts where people are well-acquainted with one another, self-selection is helpful to mitigating adverse selection issues and improving group lending repayment rates.

\subsection{Effect of Actual Microfinance Borrowing}

In our experiments in India and the Philippines we carried out a portion of our experiments with actual microfinance borrowing groups. These borrowers were affiliated with Panao MultiPurpose Cooperative and Growing Opportunity Finance, respectively, two well-established microfinance institutions in the respective countries. Our estimations across countries yield positive point effects in all instances. In estimations on contribution rates, we find the coefficient on a subject being an actual microfinance borrower to be positive in both countries and significant at the 5\% level and 1\% level in our five-country estimation in Table 3, and significant at the 5\% in our specification in column (6) of Table 4. We ask the question then, does this positive effect appear to come from some type of self-selection of trustworthy people into microfinance, or from the cumulative experience of repaying actual microfinance loans together in a borrowing group, i.e. does group borrowing activity harness existing social capital or perhaps create social capital?

In India we purposely selected some of our subjects from microfinance borrowing groups that were newly formed, but in various stages of their eight-week orientation course. They had not 
yet received actual loans. Other groups of real microfinance borrowers were veteran microfinance borrowing groups with between one and five six-month loans under their belts. Contribution rates were higher among the funded borrowers, 93.5\% to 82.1\%. Mann-Whitney tests in Table 6 for differences in contribution rates show the null of equal contribution rates between the two groups rejected at the $10 \%$ level $(p=0.079)$. In Table 4, we include a separate term for "funded borrower," where we separate out borrowers from experienced groups that had actually borrowed together from those who were merely in training. This estimation in column (3) shows that while the contribution rates of microfinance borrowers in general were 9.2 percentage points higher in India, the contribution rate of funded borrowers was an additional 14.1 percentage points higher.

One possible explanation for this result could have been that nascent borrowing groups include those that have not yet failed due to non-repayment, while veteran groups survive because they have been able to repay, and moreover have been purged of bad borrowers. However, borrowing groups in the particular branch we worked with in Chennai had exhibited virtually perfect repayment rates and extremely low levels of attrition, ruling out a difference caused by borrowing group failure or dropout. The more likely explanation is that group borrowing builds trust and positive habits in group cooperation.

The results of our experiments are consistent, for example, with those of Charness, Rigotti, and Rustichini (2007), who demonstrate in a series of experiments that group membership and group identity have powerful effects on economic behavior, especially when play is manifest to the relevant group, leading subjects to select options that favor the group. These results are important because much microfinance literature has emphasized the role of group lending in harnessing existing social capital (Zeller, 1998; Wydick, 1999; Karlan 2005). But it indeed may be the case that group lending creates as much social capital as it harnesses. Moreover, there are important implications for microfinance if this is so, because it suggests that not all of the benefits of microfinance may be found simply through impact studies on individual household consumption and welfare, but that there are significant externalities from group lending in the creation of social capital that spill over into the larger community.

\subsection{Monitoring Treatment}

Early theoretical work on group lending (Stiglitz, 1990; Banerjee, Besley, and Guinnane, 1994) suggested that peer monitoring characteristic of highly socially cohesive societies may play an important role in generating the high repayment rates observed under group lending. We sought to test these theories in our group borrowing experiment with a monitoring treatment. About 15\% of our groups in Guatemala and 25\% of our groups in the Philippines were given a monitoring treatment, in which the chairs of the subjects were re-directed inward so that information about 
investment shocks (the color of balls drawn by subjects) and contribution choices were observable to all. After the subjects took turns drawing balls, the experimenter elicited contributions simultaneously from group members by having them flip their cards to Contribute or Withhold. Subjects were allowed to change their cards in response to the decisions of others until the group converged to a Nash equilibrium, a process that usually took less than one minute. Our prior before implementing the monitoring treatment was that no-one would dare to play Withhold after publicly drawing a green ball. Our prior was incorrect.

First, we observed numerous instances of defections, even with public monitoring. As Table 6 shows, the contribution rate of $73.8 \%$ with the monitoring treatment was significantly lower than the rate of the standard non-monitoring treatment in Mann-Whitney tests $(p=0.002)$. Indeed we observed two general types of behavioral responses to perfect monitoring. In Guatemala, the contributing subjects more often took a "grin-and-bear-it" approach toward a non-contributor, faithfully maintaining their contributions to the group loan in the face of defection. This behavior was maintained in several cases as non-contributors doggedly played Withhold throughout experiments lasting seven rounds or more.

The other clear pattern both in the data and observed during the experiment was that a Withhold decision by a group member would trigger a reciprocating response by a former contributor, who would flip her sign to Withhold, which would generate a chain reaction of Withhold plays by other players to end the game. This phenomenon was more common among subjects in the Philippines. It is somewhat unclear whether either the initial reactions or subsequent reactions to a Withhold play were retaliatory or strategic in nature, Withhold of course being the optimal strategy when it is clear decisions are being made in a final round. The data clearly show contribution rates to be significantly lower in the final round of a monitoring treatment, 0.528 , than in the standard non-monitoring treatment, 0.576, $(p<0.01)$.

The estimations in Tables 2, 3, and 4 on the monitoring treatment dummy are mostly insignificant, with a positive sign in Guatemala and a negative sign in the Philippines. However, the overall effect in estimations on the five-country data reveals a significantly negative relationship $(p<0.10)$ between monitoring and group longevity. Interestingly, other recent experimental work has hinted at similar phenomena. Giné et. al. (2006) carry out microfinance games among 491 subjects in Peru, finding, in a treatment allowing for communication between members of experimental borrowing groups, that the rate of risky (but potentially high yielding) investment behavior increased strikingly, from 47 to 58 percent.

Figure 2 and Table 5 illustrate what we have come to regard as the "perilous paradox of peer monitoring". On the vertical axis of Figure 2 is the probability in a given round that a subject 
refuses to repay when she has drawn a green ball. On the horizontal axis is the number of other group members who refused to repay in that same round. The rate of refusal to repay is lower with monitoring only when there are no other members refusing to repay. With a solitary other member refusing to repay, repayment refusal becomes higher under peer monitoring with the difference between the two treatments accelerating as the number of others refusing to repay increases.

Table 5 shows OLS estimations on by-round subject contributions similar to Table 3, but includes the number of others refusing to repay as an additional independent variable. What the estimations show is the volatility of peer monitoring and its vulnerability to moral hazard contagion. The first two columns give estimates on the effect of the number of others refusing to repay in a given round on subject contributions. As seen in column (1), in the absence of direct information about defections, each additional refusal to repay by a fellow group member decreases a subject's contribution rate by 5.6 percentage points, whereas under monitoring (column 2), the response is to decrease it by 9.6 points, both significant at the $1 \%$ level.

We see in columns (3) and (4) of Table 5 that even when four or more other players have shown to be contributing (in the previous round) and it is "rational" to repay based on our results in equation (1), players' own contributions are still far more sensitive to willful non-contributions by their peers. Again both results are significant at the 1\% level, the point estimate actually increasing in column (4) to 13.0 percentage points. Although statistically insignificant, columns (5) and (6) yield an essentially identical pair of point estimates with four or more other players contributing in the current round. Because by equation (1) we know that subjects have an incentive to contribute when four or more others have contributed, what we appear observe is an emotionally based "retaliation effect" rather than a calculated strategic response to non-contribution. In short what we find is that peer monitoring seems to outperform no peer monitoring only until any type of malfeasance emerges within a borrowing group. When malfeasance does begin to occur, cooperation quickly unravels under peer monitoring.

These experimental results on our monitoring treatment contrast with the theoretical literature on microfinance, which has often underscored the importance of peer monitoring for reducing risky borrower behavior (Stiglitz, 1990; Besley, Banerjee and Guinnane, 1993). But consider any scenario in which players have an incentive to match strategies in effort or contribution when there is imperfect information about the actions of peers. Perfect information may validate members' claims of an inability to repay, even preventing a cascade of non-repayment. But with perfect information individual defections can quickly induce a downward spiral, especially when revenge adds a non-economic motive for responding to defection with defection. With imperfect information about true contribution decisions, a negative decision by one member may not trigger a 
downward spiral of defections in response because other players may attribute the defection to unavoidable mishap (the proverbial red ball). Imperfect information may thus have some useful purpose as a buffer against the contagion of malfeasance within groups. In the context of group lending, coordination on the non-repayment equilibrium may ultimately yield the greatest disadvantage to the lender, a point originally made by Besley and Coate (1995) about group lending in a full information context.

\section{Summary and Conclusions}

Does social capital matter? Results from our five-country group lending experiment suggest that it does, though occasionally in unexpected ways. We present international results from an experiment in which subjects have an incentive to contribute to a joint-liability loan to improve the likelihood that their group continues to receive additional loans. However, any member can fair better individually in a given round by withholding contribution. The stakes were high in our game relative to the income earned in our five countries; subjects could earn between half and day and two to three days' wages in less than two hours depending on their own performance and their group's performance in the experiment. We demonstrate formally that trust is important in the group lending game: A subject has an incentive to contribute if she believes a critical number of other group members will also contribute, at least four out of five other members in a group of six. We believe that there are five main findings from our five-country group lending experiment:

(1) Trust matters. Individuals with greater trust in their society (as revealed by their responses to GSS questions) displayed higher contribution rates, yielding benefits that spilled over to other members of their group. Our finding found differences in individual trust both between groups and within groups to foster significantly higher contribution rates.

(2) When people lack confidence in the behavior of others, bad outcomes for all are likely to result. This we observed in Kenya, where the average contribution rate was only 38.7 percent and where lending was terminated with borrowing groups after only 1.8 rounds. Low contribution rates were explained by low expectations about the behavior of others. Tragic events that took place in Kenya have brought to light the dearth of social trust that we observe in our experimental data, obtained less than 12 months prior to the outbreak of violence in Nairobi.

(3) The effects of social and religious homogeneity as defined by specific categories where societal tensions exist between groups are not as strong as one might expect on group loan repayment, are difficult to generalize, and are context-specific. We find mild evidence that religious homogeneity fosters better borrowing group performance, but overall the evidence is underwhelming. General expectations and trust regarding group cooperation matter more. 
(4) Social capital does not just exist innately in developing countries, but can be created through repetitive and cooperative group effort. Contribution rates were higher among real-world microfinance borrowing groups relative to real borrowing groups that had been formed and were in orientation, but had not yet taken an actual loan. Borrowers who were members of experienced groups displayed higher levels of social trust than new borrowers or the general population of subjects.

(5) The ability of people to monitor one other in group lending environments, and possibly in other situations such as work in teams, can yield negative as well as positive effects on individual behavior. When information is imperfect, non-contributions of capital (or effort) are not as contagious within a group because other may attribute them to unavoidable shocks. However, with perfect information, such behavior may trigger either retaliation or optimal defections by other agents, quickly unraveling group trust and performance.

Moreover, our research finds large and significant differences between the five countries in economic behavior and the effect of identical treatments on economic behavior. This cannot help but re-emphasize the caveats regarding the external validity of experiments and drawing general inferences from experimental and non-experimental results about economic behavior drawn from a single cultural context, especially in research devoted to understanding the relationship between social variables and economic outcomes. 


\section{References}

Abbink, Klaus; Irlenbusch, Bernd; Renner, Elke (2006). "Group Size and Social Ties in Microfinance Institutions" Economic Inquiry, Volume 44, Number 4, pp. 614-628(15)

Banerjee, Abhijit., Besley, Timothy. and Guinnane, Timothy. (1994). "Thy Neighbor's Keeper: Design of a Credit Cooperative with Theory and a Test." Quarterly Journal of Economics, vol. 102 (9), pp. 491-515.

Besley, Timothy. and Coate, Stephen. (1995). "Group lending, repayment incentives and social collateral." Journal of Development Economics, vol. 46 (1), pp. 1-18.

Bowles, Samuel and Herbert Gintis (2002). "Social Capital And Community Governance" Economic Journal, 112 (483), F419-F436.

Cassar, Alessandra, Luke Crowley, and Bruce Wydick (2007). "The Effect of Social Capital on Group Loan Repayment: Evidence from Field Experiments" Economic Journal 117, F85-106.

Case, Anne. and Lawrence Katz (1991). "The Company You Keep: The Effect of Family and Neighborhood on Disadvantaged Youth," NBER Working Paper No. 3705.

Charness, Gary, Luca Rigotti, and Aldo Rustichini (2007). "Individual Behavior and Group Membership" American Economic Review, 97 (4), pp.1140-1360.

Floro, Maria and Pan Yotopoulos (1991). Informal Credit Markets and the New Institutional Economics, Boulder: Westview Press.

Fukuyama, Francis (1996). Trust: The Social Virtues and the Creation of Prosperity, New York: Free Press, pp.26-28

Ghatak, Maitreesh. (1999) "Group Lending, Local Information and Peer Selection." Journal of Development Economics, Vol. 60 (1), pp. 27-50.

Giné, Xavier., Jakiela, Pamela., Karlan, Dean. and Morduch, Jonathan (2006). "Microfinance Games" Yale University Working Paper.

Glaeser, Edward., Bruce Sacerdote, Jose Scheinkman (1996). "Crime and Social Interactions" Quarterly Journal of Economics, 111: 508-548.

Guiso, Luigi, Paola Sapienza, and Luigi Zingales (2004). "The Role of Social Capital in Financial Development" American Economic Review, Vol. 94, No. 3, pp. 526-556.

Guth, Werner, and Reinhard Tietz (1990) "Ultimatum Bargaining Behavior: A Survey and Comparison of Experimental Results." Journal of Economic Psychology Vol. 11, pp.417-449.

Henrich, Joseph, Robert Boyd, Samuel Bowles, Colin Camerer, Ernst Fehr, Herbert Gintis, and Richard McElreath (2001). "In Search of Homo-Economicus: Behavioral Experiments in 15 Small-Scale Societies" American Economic Review Papers and Proceedings 91(2), pp.73-78.

Ichino, Andrea., and Giovanni Maggi (2000). "Work Environment and Individual Background: Explaining Regional Shirking Differentials in a Large Italian Firm" Quarterly Journal of Economics Vol. 115(3), pp.1057-90.

Karlan, Dean (2005). "Using experimental economics to measure social capital and predict financial decisions." American Economic Review, vol. 95, pp.1688-1699.

Karlan, Dean (2006). "Social connections and group banking." Economic Journal Vol.117, F52-84.

Knack, Stephen and Philip Keefer (1997). "Does Social Capital Have an Economic Payoff?: A Cross-Country Regression” Quarterly Journal of Economics, Vol.112, pp.1251-588. 
LaPorta, Rafael, Florencio Lopez-de-Salanes, Andrei Shleifer, and Robert Vishny (1997). 'Trust in Large Organizations" American Economic Review Papers and Proceedings, vol. 87, pp. 333-8.

Putnam, Robert (1993). Making Democracy Work: Civic Traditions in Modern Italy. Princeton: Princeton University Press.

Stiglitz, Joseph (1990). 'Peer Monitoring and Credit Markets.' The World Bank Economic Review, vol. 4 (3), pp. 351-366.

Udry, Christopher (1994). "Risk and Insurance in a Rural Credit Market: an Empirical Investigation in Northern Nigeria" Review of Economic Studies, Vol.61 (1), pp.495-526.

Van Tassel, E. (1999). "Group Lending under Asymmetric Information." Journal of Development Economics, vol. 60 (1), pp. 3-25.

Woolcock, Michael (1998). "Social Capital and Economic Development: Toward a Theoretical Synthesis and Policy Framework" Theory and Society vol. 27: pp.151-208.

Wydick, Bruce. (1999). "Can social cohesion be harnessed to mitigate market failures? Evidence from group lending in Guatemala." Economic Journal,, vol. 109 pp. 463-75.

Wydick, Bruce (2001). "Group lending under dynamic incentives as a borrower discipline device." Review of Development Economics, vol. 5 (3), pp. 406-420.

Zeller, M. (1998). 'Determinants of repayment performance in credit groups: the role of program design, intragroup risk pooling, and social cohesion.' Economic Development and Cultural Change, Vol.46 (3), pp. 599-620. 


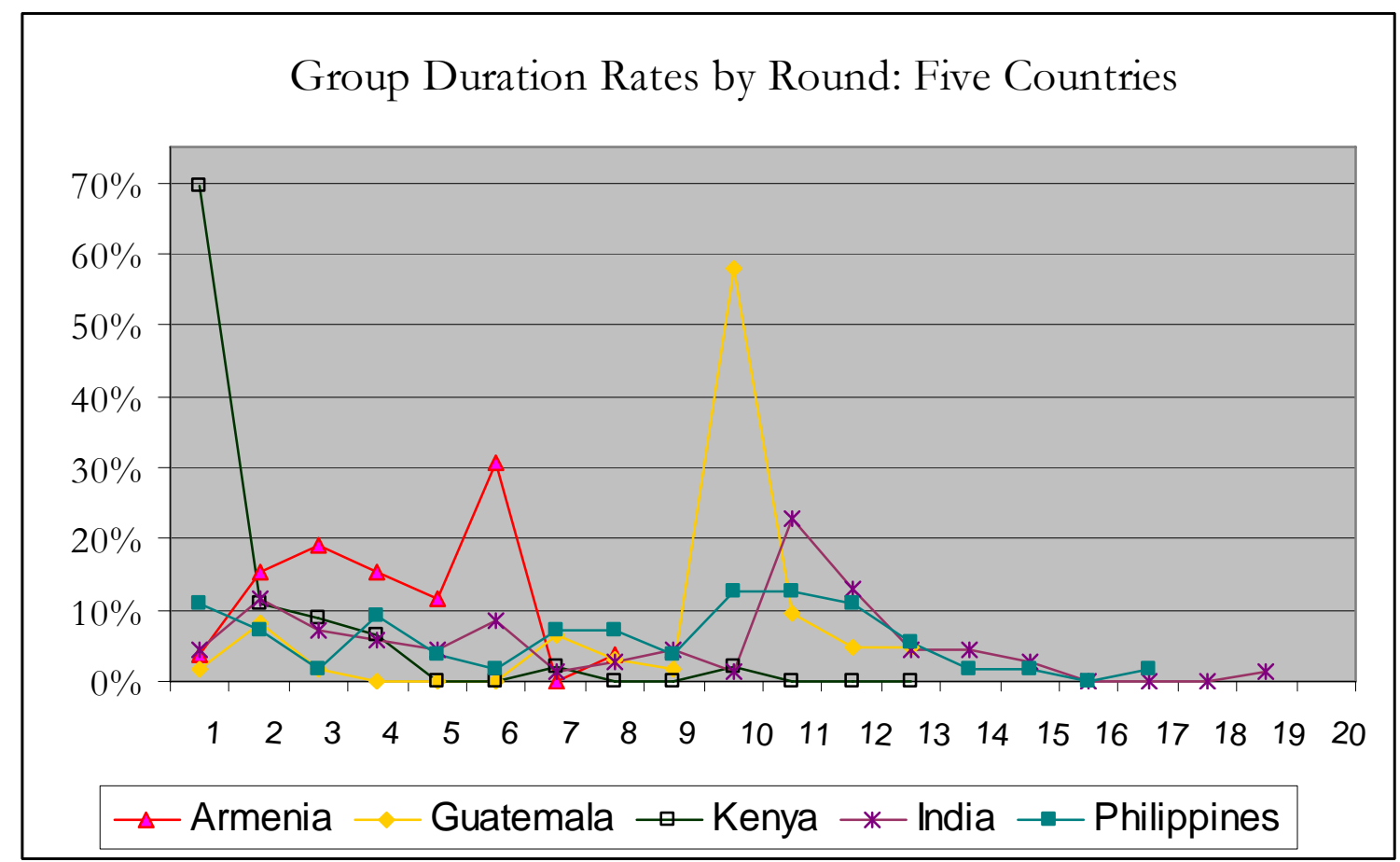

Figure 1: Group Duration Rates by Round and Country 
Table 1: Summary Statistics

---Means with Standard Deviations in Parentheses---

\begin{tabular}{|c|c|c|c|c|c|c|}
\hline Variable & Armenia & Guatemala & India & Kenya & Philippines & 5 Countries \\
\hline Num. of Groups & 26 & 62 & 70 & 46 & 55 & 259 \\
\hline Num. of Subjects & 156 & 372 & 420 & 276 & 330 & 1,554 \\
\hline $\begin{array}{l}\text { Total Num. Of Observations } \\
\text { Experimental Variables }\end{array}$ & 666 & 3,450 & 3,449 & 498 & 2,610 & 10,673 \\
\hline Num. of Rounds Exp. Lasted & 4.269 & 9.242 & 8.214 & 1.804 & 7.909 & 6.861 \\
\hline Avg. Subject Contribution Rate & 0.754 & 0.903 & 0.854 & 0.387 & 0.740 & 0.755 \\
\hline $\begin{array}{l}\text { Mean Shocks Received---Self } \\
\text { Demographic variables: }\end{array}$ & 0.187 & 0.182 & 0.199 & 0.156 & 0.153 & 1.176 \\
\hline Age & $\begin{array}{c}36.141 \\
(13.831)\end{array}$ & $\begin{array}{c}34.215 \\
(10.661)\end{array}$ & $\begin{array}{l}35.325 \\
(10.005)\end{array}$ & $\begin{array}{l}30.228 \\
(8.914)\end{array}$ & $\begin{array}{c}34.019 \\
(10.572)\end{array}$ & $\begin{array}{c}33.955 \\
(10.702)\end{array}$ \\
\hline Female Fraction & $\begin{array}{c}1.000 \\
(0.000)\end{array}$ & $\begin{array}{c}0.901 \\
(0.300)\end{array}$ & $\begin{array}{l}1.000 \\
(0.000)\end{array}$ & $\begin{array}{c}0.413 \\
(0.493)\end{array}$ & $\begin{array}{c}0.698 \\
(0.460)\end{array}$ & $\begin{array}{c}0.808 \\
(0.394)\end{array}$ \\
\hline $\begin{array}{l}\text { Mean Education } \\
(1=\text { primary., } 2=\text { mid., } 3=\text { highsch. }) \\
\text { Economic Variables: }\end{array}$ & $\begin{array}{c}1.984 \\
(0.144)\end{array}$ & $\begin{array}{c}0.934 \\
(0.665)\end{array}$ & $\cdot$ & $\begin{array}{c}1.618 \\
(0.770)\end{array}$ & $\begin{array}{c}2.234 \\
(0.802)\end{array}$ & $\begin{array}{l}1.606 \\
(0.864)\end{array}$ \\
\hline Business Owner Fraction & $\begin{array}{c}0.154 \\
(0.362)\end{array}$ & $\begin{array}{c}0.411 \\
(0.493)\end{array}$ & $\begin{array}{c}0.688 \\
(0.464)\end{array}$ & $\begin{array}{c}0.482 \\
(0.501)\end{array}$ & $\begin{array}{c}0.476 \\
(0.500)\end{array}$ & $\begin{array}{c}0.486 \\
(0.450)\end{array}$ \\
\hline Wageworker Fraction & . & $\begin{array}{c}0.161 \\
(0.368)\end{array}$ & $\begin{array}{c}0.145 \\
(0.353)\end{array}$ & $\begin{array}{c}0.322 \\
(0.468)\end{array}$ & $\begin{array}{c}0.37 \\
(0.483)\end{array}$ & $\begin{array}{c}0.237 \\
(0.426)\end{array}$ \\
\hline $\begin{array}{l}\text { Fraction with Loan in Past } \\
\text { Social Variables: }\end{array}$ & $\begin{array}{c}0.051 \\
(0.221)\end{array}$ & $\begin{array}{c}0.338 \\
(0.474)\end{array}$ & $\begin{array}{c}0.523 \\
(0.381)\end{array}$ & $\begin{array}{c}0.100 \\
(0.301)\end{array}$ & $\begin{array}{c}0.424 \\
(0.495)\end{array}$ & $\begin{array}{c}0.241 \\
(0.428)\end{array}$ \\
\hline Fraction of Life Lived in Area & $\begin{array}{c}0.486 \\
(0.305)\end{array}$ & $\begin{array}{c}0.946 \\
(0.178)\end{array}$ & $\begin{array}{c}0.793 \\
(0.296)\end{array}$ & $\begin{array}{c}0.439 \\
(0.346)\end{array}$ & $\begin{array}{c}0.503 \\
(0.332)\end{array}$ & $\begin{array}{c}0.675 \\
(0.355)\end{array}$ \\
\hline Num. of Acquaintances & $\begin{array}{c}1.436 \\
(1.296)\end{array}$ & $\begin{array}{c}3.847 \\
(1.506)\end{array}$ & $\begin{array}{c}3.468 \\
(2.202)\end{array}$ & $\begin{array}{c}3.202 \\
(1.830)\end{array}$ & $\begin{array}{c}3.492 \\
(1.388)\end{array}$ & $\begin{array}{c}3.306 \\
(1.855)\end{array}$ \\
\hline $\begin{array}{l}\text { Mean GSS Questions } \\
\text { (num. of positive replies out of } 3 \text { ) } \\
\text { Treatments: }\end{array}$ & $\begin{array}{l}1.686 \\
(1.002)\end{array}$ & $\begin{array}{c}1.341 \\
(0.868)\end{array}$ & $\begin{array}{c}1.724 \\
(1.029)\end{array}$ & $\begin{array}{c}1.337 \\
(0.813)\end{array}$ & $\begin{array}{c}1.877 \\
(0.903)\end{array}$ & $\begin{array}{c}1.592 \\
(0.952)\end{array}$ \\
\hline Fraction in Self-Select Treatment & $\begin{array}{l}0.000 \\
0.000\end{array}$ & $\begin{array}{l}0.161 \\
0.368\end{array}$ & $\begin{array}{l}0.000 \\
0.000\end{array}$ & $\begin{array}{l}0.500 \\
0.501\end{array}$ & $\begin{array}{c}0.455 \\
(0.499)\end{array}$ & $\begin{array}{c}0.224 \\
(0.417)\end{array}$ \\
\hline Fraction in Monitoring Treatment & $\begin{array}{l}0.000 \\
0.000\end{array}$ & $\begin{array}{l}0.145 \\
0.353\end{array}$ & $\begin{array}{l}0.000 \\
0.000\end{array}$ & $\begin{array}{l}0.000 \\
0.000\end{array}$ & $\begin{array}{c}0.255 \\
(0.436)\end{array}$ & $\begin{array}{c}0.089 \\
(0.285)\end{array}$ \\
\hline Fraction of Real MF Borrower & $\begin{array}{l}0.000 \\
0.000\end{array}$ & $\begin{array}{l}0.000 \\
0.000\end{array}$ & $\begin{array}{l}0.529 \\
0.450\end{array}$ & $\begin{array}{l}0.000 \\
0.000\end{array}$ & $\begin{array}{c}0.11 \\
(0.313)\end{array}$ & $\begin{array}{c}0.166 \\
(0.372)\end{array}$ \\
\hline $\begin{array}{l}\text { Num. of Others Same Religion } \\
\text { Religious Variables: }\end{array}$ & $\begin{array}{l}3.487^{1} \\
(1.505)\end{array}$ & $\begin{array}{c}3.459 \\
(1.479)\end{array}$ & $\begin{array}{c}3.457 \\
(1.595)\end{array}$ & $\begin{array}{c}4.21 \\
(1.324)\end{array}$ & $\begin{array}{c}3.852 \\
(1.535)\end{array}$ & $\begin{array}{c}3.68 \\
(1.526)\end{array}$ \\
\hline Religious Frequency & 0.000 & 2.3 & 2.171 & 1.854 & 1.5 & 1.785 \\
\hline Fraction Catholic & 0.000 & 0.618 & 0.000 & 0.000 & $0.624^{2}$ & 0.281 \\
\hline Fraction Evangelicals & 0.000 & 0.366 & $0.257^{2}$ & 0.533 & 0.000 & 0.252 \\
\hline Fraction Hindu & 0.000 & 0.000 & 0.629 & 0.000 & 0.000 & 0.171 \\
\hline Fraction Muslims & 0.000 & 0.000 & 0.086 & 0.467 & 0.288 & 0.167 \\
\hline
\end{tabular}

${ }^{1}$ Of same Pre- or Post-Perestroika generation in Armenia.

2 Data did not differentiate between Christian denominations in India and the Philippines, but Christian subjects in India were believed to be more than 90\% Evangelical Protestant while in the Philippines more than 90\% Catholic. 
Table 2: Borrowing Group Duration

Dependent Variable: Rounds Reached by Group in Microfinance Game (OLS Estimates)

\begin{tabular}{|c|c|c|c|c|c|c|c|}
\hline & $(1)$ & $(2)$ & (3) & (4) & $(5)$ & $(6)$ & $(7)$ \\
\hline & Armenia & Guatemala & India & Kenya & Philippines & $\begin{array}{l}\text { 5-Countries } \\
\text { FE: None }\end{array}$ & $\begin{array}{l}\text { 5-Countries } \\
\text { FE: Country }\end{array}$ \\
\hline Total shocks in Group & $\begin{array}{l}-1.501 * * * \\
(0.336)\end{array}$ & $\begin{array}{l}-4.279 * * * \\
(0.754)\end{array}$ & $\begin{array}{l}-0.720 \\
(1.028)\end{array}$ & $\begin{array}{l}-0.405 \\
(0.308)\end{array}$ & $\begin{array}{l}-0.778 \\
(0.935)\end{array}$ & $\begin{array}{l}-1.409 * * * \\
(0.399)\end{array}$ & $\begin{array}{l}-1.381 * * * \\
(0.380)\end{array}$ \\
\hline Mean Age & $\begin{array}{l}-0.043 \\
(0.040)\end{array}$ & $\begin{array}{l}0.109 \\
(0.081)\end{array}$ & $\begin{array}{l}-0.078 \\
(0.138)\end{array}$ & $\begin{array}{l}0.147 * * \\
(0.070)\end{array}$ & $\begin{array}{l}0.352^{* *} \\
(0.143)\end{array}$ & $\begin{array}{l}0.022 \\
(0.034)\end{array}$ & $\begin{array}{l}0.015 \\
(0.032)\end{array}$ \\
\hline Mean Education & $\begin{array}{l}2.141 \\
(4.564)\end{array}$ & $\begin{array}{l}0.663 \\
(0.920)\end{array}$ & & $\begin{array}{l}1.470 \\
(0.987)\end{array}$ & $\begin{array}{l}1.575 \\
(1.066)\end{array}$ & & \\
\hline Mean Own a Business & $\begin{array}{l}3.549 \\
(2.410)\end{array}$ & $\begin{array}{l}0.038 \\
(1.523)\end{array}$ & $\begin{array}{l}-2.601 \\
(2.615)\end{array}$ & $\begin{array}{l}0.130 \\
(1.012)\end{array}$ & $\begin{array}{l}-1.101 \\
(3.124)\end{array}$ & $\begin{array}{l}-1.657 \\
(1.025)\end{array}$ & $\begin{array}{l}-1.013 \\
(0.982)\end{array}$ \\
\hline Mean Past Loan & $\begin{array}{l}-3.354 \\
(3.135)\end{array}$ & $\begin{array}{l}-1.476 \\
(1.483)\end{array}$ & $\begin{array}{l}3.545^{* *} \\
(1.719)\end{array}$ & $\begin{array}{l}-0.747 \\
(2.466)\end{array}$ & $\begin{array}{l}-3.443 \\
(2.630)\end{array}$ & $\begin{array}{l}1.934^{*} \\
(1.028)\end{array}$ & $\begin{array}{l}0.293 \\
(1.032)\end{array}$ \\
\hline Mean Fraction Life in Area & $\begin{array}{l}-2.526 \\
(2.176)\end{array}$ & $\begin{array}{l}2.315 \\
(5.703)\end{array}$ & $\begin{array}{l}-1.402 \\
(3.579)\end{array}$ & $\begin{array}{l}3.021 \\
(3.232)\end{array}$ & $\begin{array}{l}3.326 \\
(2.619)\end{array}$ & $\begin{array}{l}4.213 * * * \\
(1.045)\end{array}$ & $\begin{array}{l}1.090 \\
(1.516)\end{array}$ \\
\hline Mean Num..Know in Group & $\begin{array}{l}-0.054 \\
(0.364)\end{array}$ & $\begin{array}{l}0.400 \\
(0.337)\end{array}$ & $\begin{array}{l}-0.589 \\
(0.782)\end{array}$ & $\begin{array}{l}-0.392 \\
(0.689)\end{array}$ & $\begin{array}{l}0.136 \\
(0.550)\end{array}$ & $\begin{array}{l}-0.466^{* *} \\
(0.235)\end{array}$ & $\begin{array}{l}-0.226 \\
(0.256)\end{array}$ \\
\hline Mean GSS Questions & $\begin{array}{l}0.299 \\
(0.918)\end{array}$ & $\begin{array}{l}1.993^{*} \\
(1.031)\end{array}$ & $\begin{array}{l}-1.070 \\
(1.071)\end{array}$ & $\begin{array}{l}-0.493 \\
(1.000)\end{array}$ & $\begin{array}{l}1.693 \\
(1.373)\end{array}$ & $\begin{array}{l}0.751 \\
(0.569)\end{array}$ & $\begin{array}{l}0.313 \\
(0.542)\end{array}$ \\
\hline Religious Homogeneity & $\begin{array}{l}1.011 \\
(0.863)\end{array}$ & $\begin{array}{l}0.534 \\
(0.716)\end{array}$ & $\begin{array}{l}0.990 \\
(1.279)\end{array}$ & $\begin{array}{l}0.953 \\
(0.755)\end{array}$ & $\begin{array}{l}0.742 \\
(1.235)\end{array}$ & $\begin{array}{l}0.240 \\
(0.525)\end{array}$ & $\begin{array}{l}0.473 \\
(0.474)\end{array}$ \\
\hline Proportion Female & & $\begin{array}{l}4.870 \\
(4.918)\end{array}$ & $\begin{array}{l}0.000 \\
(0.000)\end{array}$ & $\begin{array}{l}-0.562 \\
(1.213)\end{array}$ & $\begin{array}{l}0.881 \\
(2.198)\end{array}$ & $\begin{array}{l}2.329^{* *} \\
(1.144)\end{array}$ & $\begin{array}{l}-0.052 \\
(1.061)\end{array}$ \\
\hline Mean Wageworker & & $\begin{array}{l}0.757 \\
(1.897)\end{array}$ & $\begin{array}{l}-7.029 * * \\
(3.236)\end{array}$ & $\begin{array}{l}0.533 \\
(0.938)\end{array}$ & $\begin{array}{l}-2.627 \\
(1.579)\end{array}$ & & \\
\hline Homogeneous Gender & & $\begin{array}{l}-0.203 \\
(1.227)\end{array}$ & & $\begin{array}{l}-1.353 \\
(0.845)\end{array}$ & $\begin{array}{l}-0.653 \\
(1.489)\end{array}$ & & $\begin{array}{l}0.155 \\
(0.589)\end{array}$ \\
\hline Self-Selection Treatment & & $\begin{array}{l}9.403 \\
(7.808)\end{array}$ & & $\begin{array}{l}-3.887 \\
(2.551)\end{array}$ & $\begin{array}{l}-7.767 \\
(5.041)\end{array}$ & $\begin{array}{l}-9.463 * * * \\
(1.973)\end{array}$ & $\begin{array}{l}-6.824^{* * *} \\
(1.906)\end{array}$ \\
\hline Self-Selection *Num Know & & $\begin{array}{l}-1.672 \\
(1.702)\end{array}$ & & $\begin{array}{l}0.862 \\
(0.831)\end{array}$ & $\begin{array}{l}2.226 \\
(1.390)\end{array}$ & $\begin{array}{l}1.789 * * * \\
(0.515)\end{array}$ & $\begin{array}{l}1.534 * * * \\
(0.488)\end{array}$ \\
\hline Monitoring Treatment & & $\begin{array}{l}0.915 \\
(0.797)\end{array}$ & & & $\begin{array}{l}-4.213^{* *} \\
(2.057)\end{array}$ & $\begin{array}{l}-0.604 \\
(0.797)\end{array}$ & $\begin{array}{l}-1.258 \\
(0.835)\end{array}$ \\
\hline Microfinance Borrower & & & $\begin{array}{l}3.043 \\
(2.616)\end{array}$ & & $\begin{array}{l}-3.642 \\
(3.788)\end{array}$ & $\begin{array}{l}2.074 \\
(1.380)\end{array}$ & $\begin{array}{l}1.255 \\
(1.418)\end{array}$ \\
\hline Number of Evangelicals & & $\begin{array}{l}0.439 * * \\
(0.206)\end{array}$ & $\begin{array}{l}-0.779 \\
(1.101)\end{array}$ & $\begin{array}{l}0.240 \\
(0.152)\end{array}$ & & $\begin{array}{l}0.507 * * * \\
(0.144)\end{array}$ & $\begin{array}{l}0.463 \\
(0.407)\end{array}$ \\
\hline Number of Muslims & & & $\begin{array}{l}-0.735 \\
(1.133)\end{array}$ & $\begin{array}{l}0.000 \\
(0.000)\end{array}$ & $\begin{array}{l}0.844 * * \\
(0.365)\end{array}$ & $\begin{array}{l}0.591 * * * \\
(0.168)\end{array}$ & $\begin{array}{l}0.501 \\
(0.405)\end{array}$ \\
\hline Number of Hindus & & & $\begin{array}{l}-0.879 \\
(1.067)\end{array}$ & & & $\begin{array}{l}0.455^{*} \\
(0.233)\end{array}$ & $\begin{array}{l}0.162 \\
(0.471)\end{array}$ \\
\hline Number of Catholics & & & & & & $\begin{array}{l}0.837^{* * *} \\
(0.154)\end{array}$ & $\begin{array}{l}0.124 \\
(0.374)\end{array}$ \\
\hline Armenia & & & & & & & $\begin{array}{l}-3.316 \\
(2.115)\end{array}$ \\
\hline Guatemala & & & & & & & $\begin{array}{l}0.666 \\
(1.191)\end{array}$ \\
\hline Kenya & & & & & & & $\begin{array}{l}-7.489 * * * \\
(0.864)\end{array}$ \\
\hline India & & & & & & & $\begin{array}{l}-0.756 \\
(1.462)\end{array}$ \\
\hline Constant & $\begin{array}{l}3.342 \\
(9.239)\end{array}$ & $\begin{array}{l}-2.473 \\
(7.318)\end{array}$ & $\begin{array}{l}21.831^{* *} \\
(8.273)\end{array}$ & $\begin{array}{l}-4.933 \\
(3.408)\end{array}$ & $\begin{array}{l}-10.290 \\
(7.234)\end{array}$ & $\begin{array}{l}0.452 \\
(2.107)\end{array}$ & $\begin{array}{l}7.716^{* *} \\
(3.006)\end{array}$ \\
\hline Observations & 26 & 62 & 70 & 46 & 52 & 259 & 259 \\
\hline R-squared & 0.48 & 0.60 & 0.23 & 0.35 & 0.60 & 0.36 & 0.49 \\
\hline
\end{tabular}

Robust standard errors in parentheses. * significant at $10 \%$; ** significant at $5 \%$; *** significant at $1 \%$ 
Table 3: Individual Repayment Decisions

Dependent Variable: 1 = Individual Contributes in Round $x$ ---Binary Logit on Pooled Panel Data, Clustered Standard Errors at Group Level---

\begin{tabular}{|c|c|c|c|c|c|c|c|c|}
\hline & $(1)$ & $(2)$ & (3) & (4) & (5) & $(6)$ & $(7)$ & $(8)$ \\
\hline & Armenia & Guatemala & India & Kenya & Philippines & 5-Countries & 5-Countries & 5-Countries \\
\hline Variable & & & & & & FE: None & FE: Country & FE: Group \\
\hline \multirow[t]{2}{*}{ Lag Subject Shock } & 0.079 & 0.092 & $0.369 *$ & -0.670 & -0.330 & 0.058 & 0.032 & -0.101 \\
\hline & $(0.351)$ & $(0.259)$ & $(0.210)$ & $(0.452)$ & $(0.224)$ & $(0.109)$ & $(0.113)$ & $(0.115)$ \\
\hline \multirow[t]{2}{*}{ Lag Shocks Others } & -0.130 & -0.153 & -0.004 & -0.055 & -0.038 & 0.021 & -0.013 & $-0.149 * * *$ \\
\hline & $(0.121)$ & $(0.127)$ & $(0.103)$ & $(0.320)$ & $(0.091)$ & $(0.052)$ & $(0.052)$ & $(0.056)$ \\
\hline \multirow[t]{2}{*}{ Age } & 0.011 & 0.002 & 0.001 & $0.065^{*}$ & 0.006 & 0.010 & $0.010^{*}$ & $0.013^{* * *}$ \\
\hline & $(0.014)$ & $(0.022)$ & $(0.012)$ & $(0.037)$ & $(0.009)$ & $(0.006)$ & $(0.006)$ & $(0.005)$ \\
\hline \multirow[t]{2}{*}{ Education } & -0.133 & -0.105 & & -0.004 & -0.210 & & & \\
\hline & $(1.034)$ & $(0.218)$ & & $(0.300)$ & $(0.146)$ & & & \\
\hline \multirow[t]{2}{*}{ Female } & & 0.432 & & -0.063 & 0.042 & $0.589 * * *$ & 0.099 & 0.209 \\
\hline & & $(0.759)$ & & $(0.413)$ & $(0.185)$ & $(0.147)$ & $(0.158)$ & $(0.147)$ \\
\hline \multirow[t]{2}{*}{ Wage worker } & & $-0.785^{*}$ & $-0.841 * * *$ & 0.249 & -0.217 & & & \\
\hline & & $(0.450)$ & $(0.277)$ & $(0.453)$ & $(0.183)$ & & & \\
\hline \multirow[t]{2}{*}{ Own Business } & -0.169 & 0.216 & -0.095 & -0.355 & 0.070 & -0.014 & 0.009 & 0.091 \\
\hline & $(0.425)$ & $(0.358)$ & $(0.245)$ & $(0.623)$ & $(0.231)$ & $(0.125)$ & $(0.140)$ & $(0.116)$ \\
\hline \multirow[t]{2}{*}{ Past Loan } & -0.239 & 0.428 & -0.040 & -0.578 & $-0.450^{*}$ & -0.046 & -0.041 & 0.182 \\
\hline & $(0.609)$ & $(0.434)$ & $(0.334)$ & $(0.594)$ & $(0.246)$ & $(0.172)$ & $(0.175)$ & $(0.125)$ \\
\hline \multirow[t]{2}{*}{ Frac of Life in Area } & 0.135 & -0.957 & -0.245 & 0.504 & $0.435^{*}$ & $0.637 * * *$ & 0.054 & -0.069 \\
\hline & $(0.375)$ & $(1.221)$ & $(0.371)$ & $(0.940)$ & $(0.236)$ & $(0.173)$ & $(0.153)$ & $(0.158)$ \\
\hline \multirow[t]{2}{*}{ No.Know in Group } & -0.030 & $0.305^{*}$ & 0.034 & 0.107 & $-0.124 * * *$ & 0.037 & 0.016 & 0.026 \\
\hline & $(0.099)$ & $(0.169)$ & $(0.062)$ & $(0.128)$ & $(0.046)$ & $(0.039)$ & $(0.039)$ & $(0.035)$ \\
\hline \multirow[t]{2}{*}{ GSS } & 0.117 & $0.471 *$ & 0.100 & $0.597 * *$ & 0.141 & $0.127^{*}$ & $0.184^{* * *}$ & $0.221 * * *$ \\
\hline & $(0.143)$ & $(0.250)$ & $(0.135)$ & $(0.249)$ & $(0.118)$ & $(0.068)$ & $(0.070)$ & $(0.050)$ \\
\hline \multirow[t]{2}{*}{ Relig. as Self Ttmt. } & 0.013 & 0.054 & 0.131 & 0.383 & $-0.232^{* * *}$ & -0.034 & 0.024 & $0.139 * * *$ \\
\hline & $(0.107)$ & $(0.150)$ & $(0.087)$ & $(0.334)$ & $(0.079)$ & $(0.053)$ & $(0.053)$ & $(0.054)$ \\
\hline \multirow[t]{2}{*}{ Town as Self Ttmt. } & & 0.272 & & & & & & \\
\hline & & $(0.194)$ & & & & & & \\
\hline \multirow[t]{2}{*}{ Self-Selection Ttmt. } & & -1.744 & & -1.183 & $-1.193^{*}$ & $-1.69 * * *$ & $-1.46^{* * *}$ & \\
\hline & & $(1.083)$ & & (1.087) & $(0.632)$ & $(0.492)$ & $(0.432)$ & \\
\hline \multirow[t]{2}{*}{ Self-Sel*NumKnow } & & -0.033 & & -0.040 & $0.348^{* *}$ & $0.214^{*}$ & $0.191 *$ & 0.042 \\
\hline & & $(0.243)$ & & $(0.242)$ & $(0.156)$ & $(0.118)$ & $(0.100)$ & $(0.086)$ \\
\hline \multirow[t]{2}{*}{ Monitoring Ttmt. } & & -0.426 & & & -0.373 & 0.060 & 0.186 & \\
\hline & & $(0.985)$ & & & $(0.349)$ & $(0.297)$ & $(0.298)$ & \\
\hline \multirow[t]{2}{*}{ Microf. Borrower } & & & $1.044 * * *$ & & 0.791 & $0.794 * *$ & $0.977^{* * *}$ & \\
\hline & & & $(0.383)$ & & $(0.693)$ & $(0.321)$ & $(0.320)$ & \\
\hline \multirow[t]{2}{*}{ Evangelical } & & $-1.027 *$ & $0.726^{* * *}$ & 0.653 & & $0.713^{* * *}$ & $-0.939 * *$ & \\
\hline & & $(0.540)$ & $(0.259)$ & $(0.427)$ & & $(0.220)$ & $(0.467)$ & \\
\hline \multirow[t]{2}{*}{ Muslim } & & & $0.985^{* * *}$ & & 0.317 & $0.748^{* * *}$ & -0.287 & \\
\hline & & & $(0.378)$ & & $(0.231)$ & $(0.218)$ & $(0.420)$ & \\
\hline \multirow[t]{2}{*}{ Catholic } & & & & & & $1.056^{* * *}$ & -0.349 & \\
\hline & & & & & & $(0.246)$ & $(0.401)$ & \\
\hline \multirow[t]{2}{*}{ Hindu } & & & & & & 0.231 & $-1.47 * * *$ & \\
\hline & & & & & & $(0.276)$ & $(0.519)$ & \\
\hline Constant & 0.762 & 1.300 & 0.961 & $-4.374 *$ & $2.662^{* * *}$ & -0.280 & $0.927 * *$ & \\
\hline & $(2.218)$ & (1.698) & $(0.745)$ & $(2.393)$ & $(0.703)$ & $(0.365)$ & $(0.447)$ & \\
\hline Observations & 436 & 2,093 & 2,183 & 149 & 1,360 & 6,640 & 6,640 & 5,088 \\
\hline
\end{tabular}

\footnotetext{
* significant at $10 \%$; $* *$ significant at $5 \%$; *** significant at $1 \%$. Clustered standard errors at the group level in parentheses
} 
Table 4: Individual Repayment Decisions

Dependent Variable: Fraction of Times Repaid Divided by Opportunities to Repay

Variable

Avg Subject Shock

Avg Shocks Others

Age

Education

Female

Wage worker

Own Business

Past Loan

Frac of Life in Area

No.Know in Group

GSS

Relig. as Self Ttmt.

Town as Self Ttmt.

Self-Selection Ttmt.

Self-Sel*NumKnow

Monitoring Ttmt.

Microf. Borrower

Funded Borrower

Evangelical

Muslim

Catholic

Hindu

Constant

Observations

$\begin{array}{ll}0.798^{*} & 0.731^{\text {*** }} \\ (0.420) & (0.139) \\ 152 & 302 \\ 0.05 & 0.16\end{array}$

0.05

(1) Armenia

\subsection{6}

(0.179)

$-0.033$

(0.036)

0.001

(0.002)

$-0.084$

(0.186)

$-0.044$

(0.090)

0.047

$(0.125)$

0.060

(0.066)

0.004

(0.016)

0.031

(0.026)

$(0.017)$

R-squared

Clustered standard errors
(2) Guatemala

India

(3)

0.080

(0.100)

$-0.143^{* * *}$

(0.050)

0.002

(0.002)

0.004

(0.018)

0.033

(0.053)

$-0.032$

(0.038)

0.036

(0.022)

0.046

(0.028)

0.005

(0.094)

$0.030 * *$

(0.012)

$0.042 * *$

(0.016)

$-0.002$

(0.014)

0.006

(0.015)

0.052

(0.101)

$-0.024$

(0.022)

0.014

(0.030)

0.16

$0.194 * *$

(0.103)

$-0.008$

(0.036)

$-0.001$

(0.001)

(4)

Kenya

$-0.108$

(0.243)

0.063

$(0.040)$

$0.015^{* * *}$

(0.003)

0.043

(0.038)

0.076

(0.078)

-0.130 ***

0.054

(0.062)

(0.045)

0.029

(0.035)

$-0.0680$

(0.067)

$-0.052$

(0.039)

$-0.022 * * *$

(0.008)

0.016

(0.014)

0.009

(0.009)

$-0.013$

(0.072)

$-0.010$

(0.120)

$-0.004$

(0.098)

0.001

(0.029)

0.044

(0.043)

0.023

(0.022)

0.030

(0.032)

$-0.023$

(0.041)

0.022

(0.049)

$-0.138^{* * *}$

(0.049)

0.102

(0.063)

$-0.016$

$$
\text { (0.011) }
$$

0.023

0.023
$(0.020)$

$-0.016$

$$
-0.216
$$

$$
\text { (0.134) }
$$

0.017

(0.036)

$$
\begin{aligned}
& -0.247^{* *} \\
& (0.118) \\
& 0.049 \\
& (0.031) \\
& -0.107^{*} \\
& (0.062) \\
& 0.025 \\
& (0.104)
\end{aligned}
$$

(0.042)

$0.143^{* *}$

(0.071)

$$
-0.019
$$

(0.038)

$0.077^{* *}$

(0.032)

$0.093^{* *}$

(0.046)

\subsection{7}

(0.081)

$(0.080)$

378

(0.145)

207

0.12
(5)

Philippines

0.069

(0.156)

0.040

(0.051)

0.002

(0.002)

$-0.018$

(0.016)

(6) 5-Countries

FE: None

$0.245^{* * * *}$

(0.067)

$-0.008$

(0.020)

$0.003 * * *$

(0.001)

$0.122^{* * *}$

(0.033)

$-0.011$

(0.021)

0.018

(0.023)

$0.113^{* * *}$

(0.030)

$-0.005$

(0.006)

$0.026^{* * *}$

(0.010)

$-0.001$

(0.007)

(0.081)

$0.036^{*}$

(0.019)

$-0.004$

(0.037)

$0.089 * *$

(0.041)

0.031
$(0.049)$

0.029

(0.033)

$-0.038$

(0.043)

$0.133 * * *$

(0.034)

$-0.008$

(0.040)

0.431 ***

(0.064)

1,354

0.20

$(0.147)$

244

0.16
$-0.350 * * *$

5-Countries

FE: Country

$0.167^{* * *} *$

(0.062)

$-0.006$

(0.019)

$0.002^{* *}$

(0.001)

\subsection{6}

(0.030)

0.007

(0.020)

$-0.005$

(0.022)

0.009

(0.031)

$-0.002$

(0.006)

$0.027 * * *$

(0.009)

0.008

(0.006)

$-0.207^{* * *}$

(0.076)

0.026

(0.017)

$-0.045$

(0.039)

0.060

(0.041)

0.20

(8)

5-Countries

FE: Group 0.040

(0.738)

$-0.003$

(0.732)

$0.002 * *$

(0.001)

0.001 
Dependent Variable: Subject Contributed in round $\mathrm{j}>1$ ?

---OLS Estimates, Clustered Standard Errors---

\begin{tabular}{|c|c|c|c|c|c|c|}
\hline & (1) & (2) & (3) & (4) & (5) & (6) \\
\hline & No & & No Monitor & Monitoring & No Monitor & Monitor \\
\hline & Monitoring & Monitoring & $\geq 4$ LagCont & $\geq 4$ LagCont & $\geq 4$ Contrib & $\geq 4$ Contrib \\
\hline \multirow{2}{*}{ Lag Contributions Others } & $0.013^{*}$ & 0.009 & 0.009 & 0.020 & $0.017^{*}$ & 0.006 \\
\hline & $(0.007)$ & $(0.011)$ & $(0.013)$ & $(0.033)$ & $(0.009)$ & $(0.018)$ \\
\hline \multirow[t]{2}{*}{ Others Refuse } & $-0.056 * * *$ & $-0.096 * * *$ & $-0.058 * * *$ & $-0.130 * * *$ & -0.065 & -0.129 \\
\hline & $(0.013)$ & $(0.029)$ & $(0.019)$ & $(0.028)$ & $(0.043)$ & $(0.116)$ \\
\hline \multirow[t]{2}{*}{ Shocks Other } & -0.004 & -0.004 & -0.001 & -0.006 & -0.018 & 0.008 \\
\hline & $(0.006)$ & $(0.011)$ & $(0.007)$ & $(0.012)$ & $(0.018)$ & $(0.039)$ \\
\hline Observations & 2,937 & 517 & 1,910 & 313 & 1,785 & 293 \\
\hline R-squared & 0.07 & 0.24 & 0.09 & 0.30 & 0.09 & 0.25 \\
\hline
\end{tabular}

Clustered standard errors (at group level) in parentheses with fixed effects for country, round, and religion, and controls for subject characteristics, social variables, and treatments.

* significant at $10 \%$; ** significant at 5\%; *** significant at $1 \%$ 
Figure 2

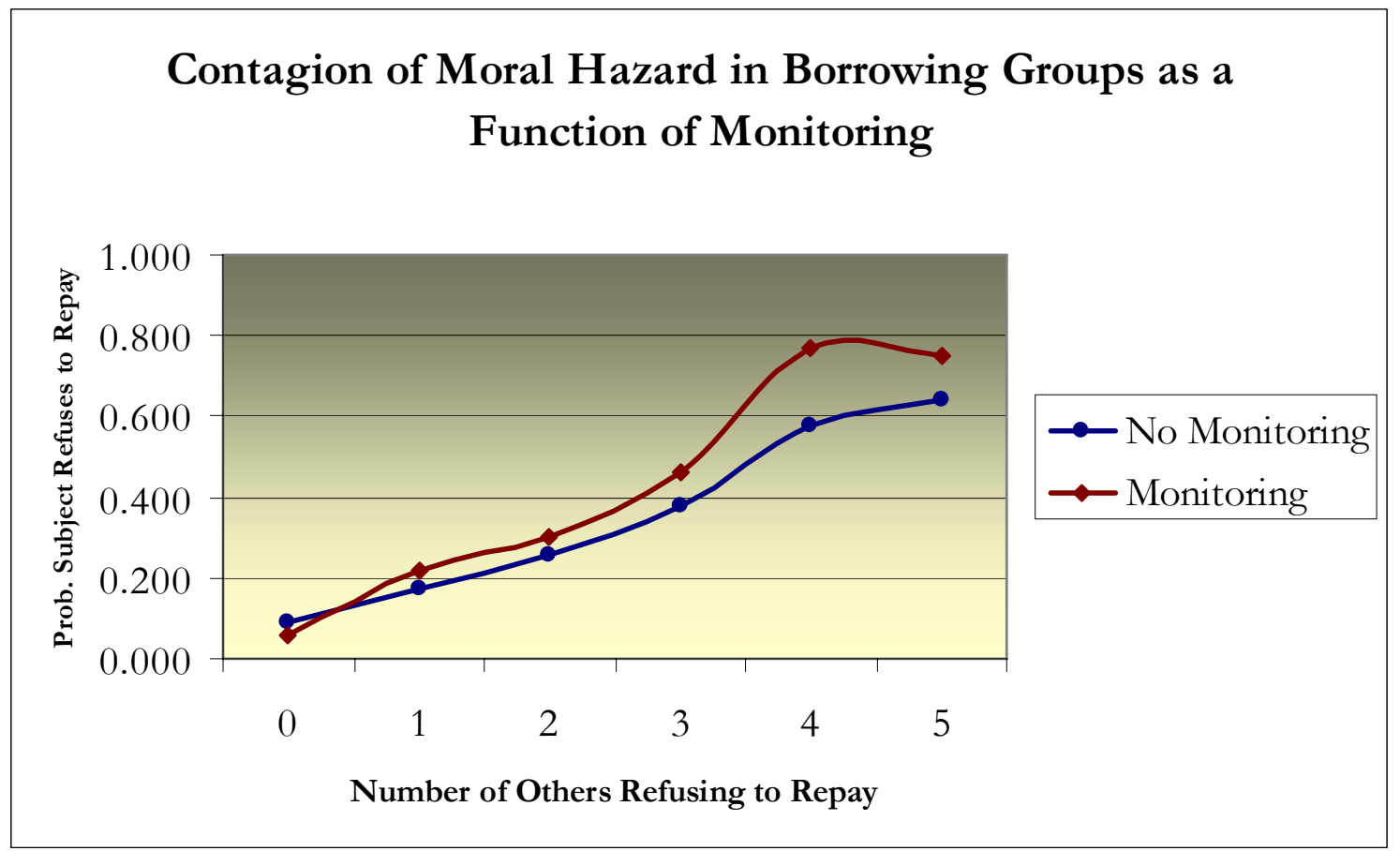


Table 6: Tests for Differences in Means

$\mathrm{H}_{0}$ : Avg. Contribution Rate $($ Treatment $=0)=$ Avg. Contribution Rate (Treatment=1)

\begin{tabular}{|c|c|c|c|c|c|}
\hline \multirow{2}{*}{$\begin{array}{l}\text { Treatment } \\
\text { Female vs. }\end{array}$} & \multirow{3}{*}{$\begin{array}{l}\text { Country Sample } \\
\text { Guatemala, Kenya, Philippines }\end{array}$} & $N$ & \multicolumn{2}{|c|}{ Mean (St. Dev.) } & \multirow{3}{*}{$\begin{array}{l}\text { Mann-Whitney test } \\
z=-7.262 \\
\text { Prob }>|z|= \\
0.000\end{array}$} \\
\hline & & 650 & 0.772 & $(0.347)$ & \\
\hline Male & & 276 & 0.573 & $(0.427)$ & \\
\hline Evangelical vs. & Guatemala, India, Kenya & 370 & 0.727 & $(0.398)$ & $z=1.873$ \\
\hline Non-Evangelical & & 651 & 0.778 & $(0.368)$ & $\begin{array}{l}\text { Prob }>|z|= \\
0.066\end{array}$ \\
\hline Catholic vs. & Guatemala, Philippines & 425 & 0.819 & $(0.295)$ & $z=-1.150$ \\
\hline Non-Catholic & & 262 & 0.840 & $(0.242)$ & $\begin{array}{l}\text { Prob }>|z|= \\
0.250\end{array}$ \\
\hline Muslim vs. & India, Kenya, Philippines & 245 & 0.601 & $(0.416)$ & $z=5.191$ \\
\hline Non-Muslim & & 725 & 0.731 & $(0.361)$ & $\begin{array}{l}\text { Prob }>|z|= \\
0.000\end{array}$ \\
\hline Hindu vs. & India & 255 & 0.830 & $(0.297)$ & $z=1.828$ \\
\hline Non-Hindu & & 152 & 0.895 & $(0.226)$ & $\begin{array}{l}\text { Prob }>|z|= \\
0.068\end{array}$ \\
\hline Borrower vs. & India, Philippines & 243 & 0.864 & $(0.280)$ & $z=-7.005$ \\
\hline Non-Borrower & & 480 & 0.730 & $(0.773)$ & $\begin{array}{l}\text { Prob }>|z|= \\
0.000\end{array}$ \\
\hline Self-Select vs. & Guatemala, Kenya, Philippines & 322 & 0.582 & $(0.428)$ & $z=6.244$ \\
\hline Non-Self-Select & & 610 & 0.780 & $(0.338)$ & $\begin{array}{l}\text { Prob }>|z|= \\
0.000\end{array}$ \\
\hline Monitor vs. & Guatemala, Philippines & 133 & 0.738 & $(0.344)$ & $\begin{array}{l}z=3.128 \\
\operatorname{Prob}>|z|=\end{array}$ \\
\hline Non-Monitor & & 554 & 0.849 & $(0.253)$ & 0.002 \\
\hline Funded Borrower & India & 30 & 0.935 & $(0.169)$ & $\begin{array}{l}z=-1.755 \\
\text { Prob }>|z|=\end{array}$ \\
\hline vs. Non-Funded & & 123 & 0.821 & $(0.324)$ & 0.079 \\
\hline
\end{tabular}

